\title{
Using Vertical Rock Uplift Patterns to Constrain the Three-Dimensional Fault Configuration in the Los Angeles Basin
}

\author{
by Andrew J. Meigs, Michele L. Cooke, and Scott T. Marshall
}

\begin{abstract}
Comparison of geologic uplift patterns with results of three-dimensional mechanical models provides constraints on the fault geometry compiled by the Southern California Earthquake Center community fault model in the northern Los Angeles basin, California. The modeled uplift matches well the geologic pattern of uplift associated with the Santa Fe Springs and Coyote Hills segments of the Puente Hills thrust fault but does not match structures to the west of the San Gabriel River. To better match the geologic patterns in this area, alternative fault configurations were tested. The best match to geologic uplift is attained with a model incorporating (1) a steep blind thrust fault at the location of the Los Angeles segment of the Puente Hills thrust system (following interpretations of the Las Cienegas fault geometry at this location), (2) removal of an inferred linking fault between the Raymond and Hollywood faults, and (3) lateral continuation of the Lower Elysian Park fault, a blind lowangle detachment at $>10 \mathrm{~km}$ depth, along strike to the northwest. These geometric revisions alter the connectivity of northern Los Angeles basin faults and significantly improve the match of model uplift pattern to geologic data. Model results suggest that fault connectivity may be more important in governing fault slip rate than are fault dip and fault area. The preferred model alters slip rates by $>0.2 \mathrm{~mm} / \mathrm{yr}$ for the Upper Elysian Park, Hollywood, Lower Elysian Park, Raymond, Sierra Madre West, and Verdugo faults. Additionally, the preferred model alters the surface area of several faults in the northern Los Angeles basin, such as the Puente Hills thrust and the Lower Elysian Park fault, which may have important implications for seismic hazard assessment in the northern Los Angeles basin.
\end{abstract}

\section{Introduction}

Accurate three-dimensional fault surface representations are imperative for understanding how regional fault networks accommodate strain, how they interact, and how they are organized internally. The Southern California Earthquake Center has developed a three-dimensional model of southern California's network of active faults, the community fault model (CFM) (Plesch et al., 2002), in order to improve regional geophysical modeling efforts and model seismic hazard (e.g., Field et al., 2005). One of the most topologically complex regions of the southern California fault network is the northern Los Angeles (LA) basin, where northwest-southeast trending strike-slip faults of the Peninsular ranges intersect with the east-west trending reverse and oblique faults of the Transverse ranges (Fig. 1) (e.g., Wright, 1991; Meigs and Oskin, 2002). A network of about 34 active fault surfaces comprises the CFM within the northern LA basin. This highly urbanized region is vulnerable to seismic damage that might result from even small or moderate earthquakes on nearby faults. Validation of the CFM within the LA basin will provide accurate fault surface area and will con- strain fault configurations for use in geophysical models of slip rates, recurrence intervals, and rupture propagation. This study explores the details of the complex fault configuration within the CFM in this region in an effort to define what fault geometries (dip, connectivity, length) are compatible with geological uplift patterns revealed by deformed stratigraphic horizons.

Fault surfaces comprising the CFM have been assembled from a range of geological and geophysical data sets (Plesch et al., 2002). Faults such as the Northridge blind thrust and the Puente Hills thrust identified themselves in earthquakes (Hauksson et al., 1988; Hauksson and Jones, 1989; Yeats and Huftile, 1995; Hudnut et al., 1996; Carena and Suppe, 2002). Industry geophysical and geological data have been used to locate and characterize fault location, orientation, and slip rate (Huftile and Yeats, 1995; Schneider et al., 1996; Shaw and Shearer, 1999; Tsutsumi and Yeats, 1999; Tsutsumi et al., 2001; Shaw et al., 2002; Myers et al., 2003). Other fault locations and geometries have been inferred from structural models (Davis et al., 1989; Shaw and Suppe, 1996; 


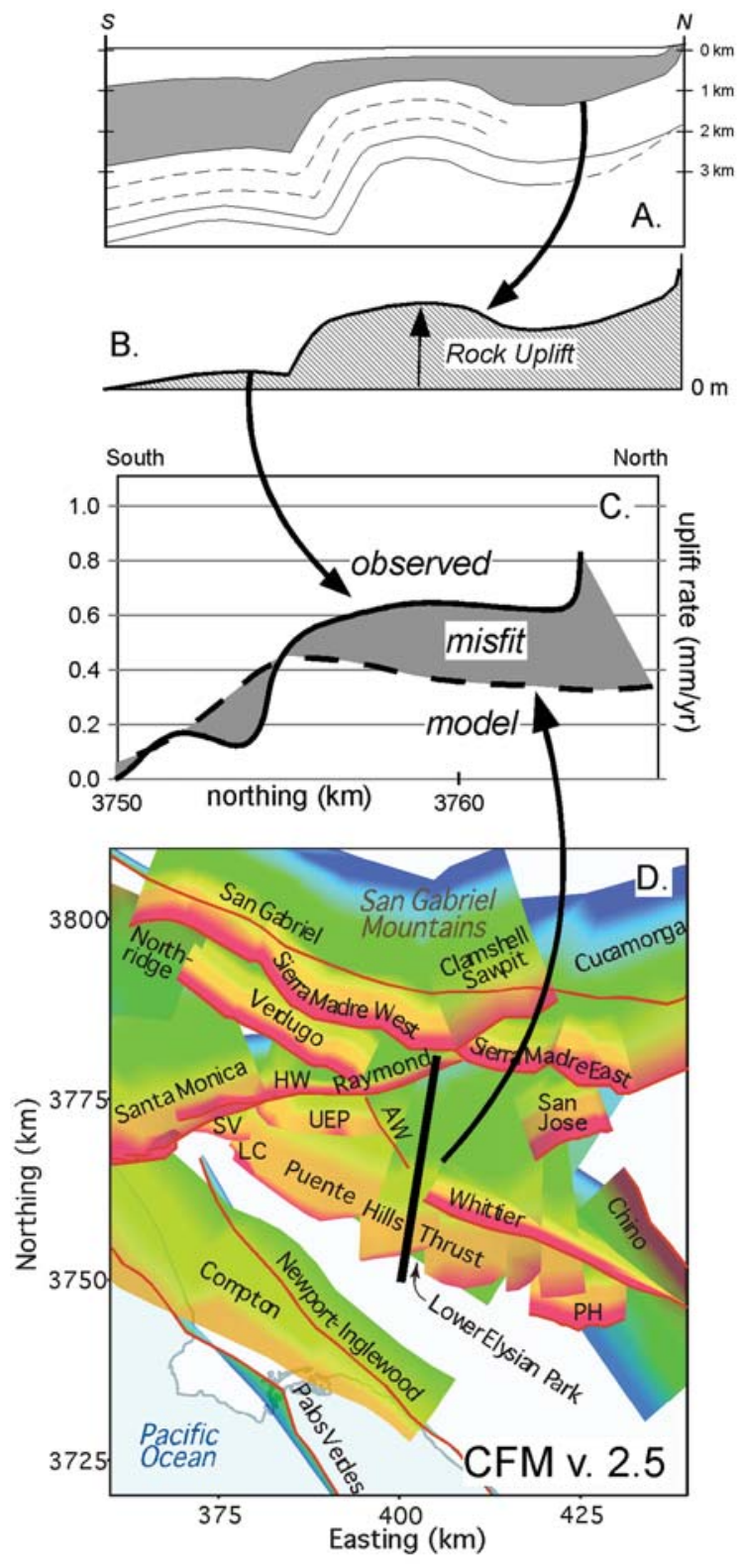

Figure 1. Rock uplift rate and numerical model uplift rate integration. (a) Deformed stratigraphic markers (i.e., top or bottom contacts of stratigraphic formations (shaded unit) from cross sections are used to constrain marker depth across strike. (b) Rock uplift is inverted from depth by measuring marker structural relief relative to a reference depth. The greatest depths of a marker in a basin or at the center of a syncline represent potential choices for reference depths. (c) Rock uplift rate is the rock uplift divided by the age of the marker; differences between measured and modeled uplift rate represent data-model misfit. (d) Three-dimensional active fault surfaces within the LA metropolitan region are color shaded to $27.5-\mathrm{km}$ depth. Warmer colors indicate shallower depths so that red is 0 and blue is 27.5-km depth. Vertical faults are represented as red lines. Selected faults include the following: Hollywood, HW; Peralta Hills, PH; Alhambra Wash, AW; Las Cienegas, LC; San Vicente, SV; West Beverly Hills, WBH; and Upper Elysian Park, UEP. Regional shortening, constrained by geodetic data, is imposed on the model faults. Model uplift (c) is extracted from the uplift rate field predicted by the model parallel to the bold line (d).
Meigs et al., 2003). Relatively few fault shapes and extents are known across the seismogenic layer (e.g., Shaw and Shearer, 1999; Carena and Suppe, 2002), and most fault characteristics are well defined for only the upper few kilometers of the crust (e.g., Schneider et al., 1996; Tsutsumi et al., 2001; Myers et al., 2003). To midcrustal depths, the seismogenic layer is well defined across the LA basin (Nazareth and Hauksson, 2004). Between the upper crust and the base of the seismogenic layer, fault geometry is defined via geometrical models, projection, mechanical models, aftershock sequences, hypocentral locations, and interpretation (e.g., Schneider et al., 1996; Tsutsumi and Yeats, 1999; Carena and Suppe, 2002; Shaw et al., 2002; Griffith and Cooke, 2004). Plesch et al. (2002) determined that $95 \%$ of the seismic moment release from earthquakes between 1981 and 2003 in southern California fell within $4 \mathrm{~km}$ of the surfaces of faults within the CFM. Whereas better constraint of subsurface fault geometry can be achieved via new seismic imaging or collection of additional geologic data, mechanical modeling represents a viable, economical alternative to exploring fault geometries within the seismogenic layer.

In this study, we use three-dimensional mechanical model results to test the CFM fault network and alternative configurations using geologic uplift data (Fig. 1). Maps of rock uplift were derived from well data and cross-sectional interpretations of the depth of the base of the Pico Member of the Fernando Formation (2.9 Ma), which is well represented throughout the northern LA basin (Blake, 1991; Wright, 1991; Schneider et al., 1996; Tsutsumi et al., 2001; Myers et al., 2003). To simulate deformation, we utilize threedimensional mechanical models that contain fault surfaces defined by the CFM working group and that are deformed according to regional geodetic information. Blind thrust fault dip and the extent of low-angle detachments are varied within the numerical models, and the resultant uplift patterns are compared to the spatial variation of rock uplift. The integrated geologic and modeling evaluative approach we employ for this relatively well-studied region of southern California serves to validate portions of the CFM, identifies areas of mismatch between CFM-based models of uplift and geologic data, and explores alternative fault configurations that better match the geologic uplift pattern in the mismatched regions.

\section{Major Structures of the Northern Los Angeles Basin}

Two distinct structural domains, the central trough and the northern shelf, comprise the northern LA basin. The central trough is a regionally continuous northwest-trending syncline that defines the basin axis where the sedimentary fill reaches its maximum thickness (Wright, 1991). The northern shelf defines the northern and northeastern margin of the central trough and comprises a series of active folds and blind and surface-cutting faults (Fig. 2). In the west, between Santa Monica and the San Gabriel River, major structures of 


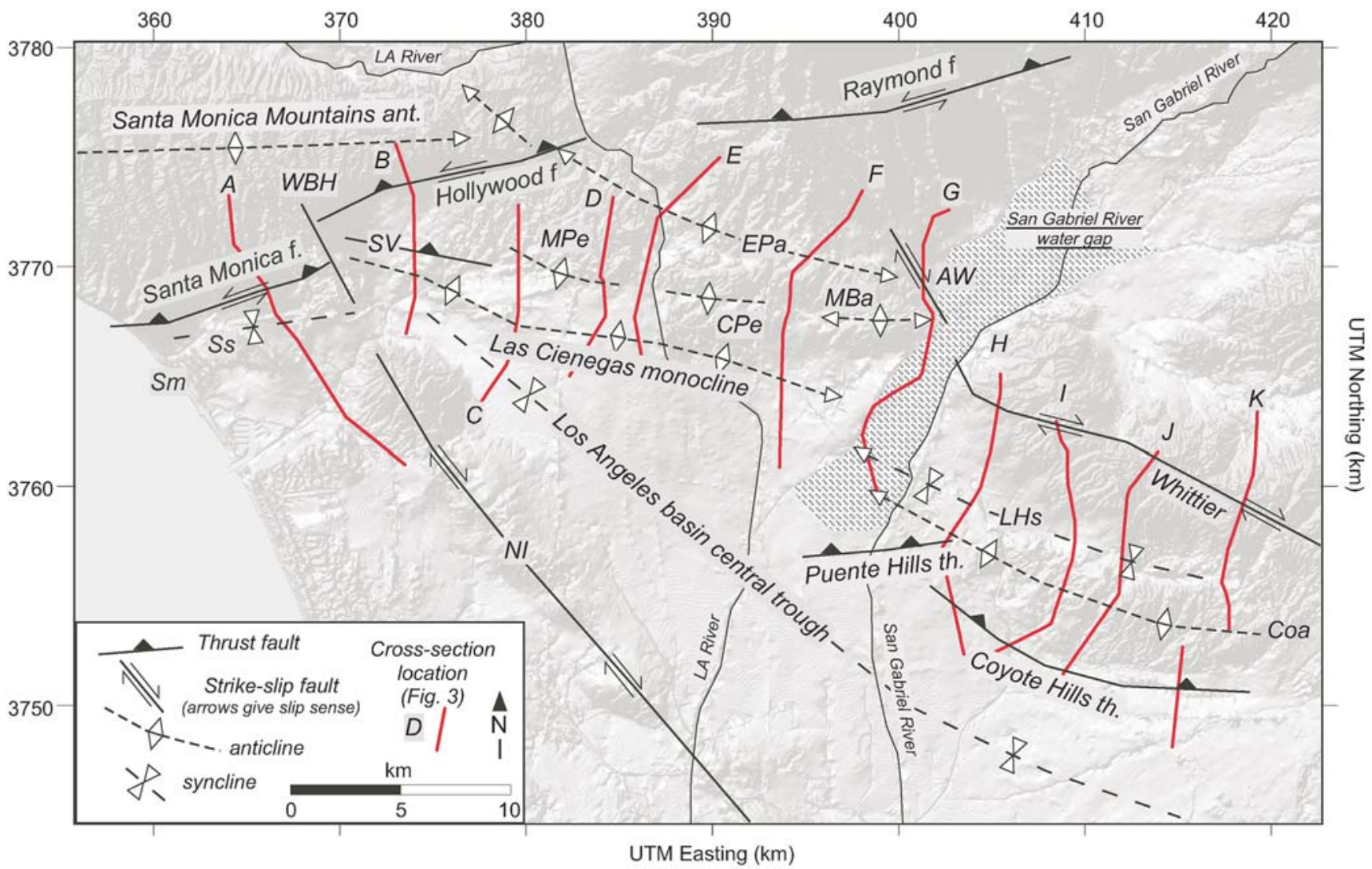

Figure 2. Major structures in the northern LA basin are folds, blind and emergent thrust faults, and strike-slip faults in the boundary region between the east-west trending Transverse ranges and northwest-trending Peninsular ranges structural provinces (Wright, 1991; Meigs and Oskin, 2002). Major thrust faults include the Raymond, Hollywood, Santa Monica, San Vincente (SV), Puente Hills blind thrust, and Coyote Hills blind thrust. Strike-slip faults include the Newport-Inglewood (NI), Alhambra Wash (AW), and Whittier faults. Key folds include the Santa Monica Mountains anticlinorium, the Elysian Park anticlinorium (EPA), the McArthur Park escarpment (MPE), the Coyote Pass escarpment (CPE), the Montebello Hills anticline (MBA), the La Cienegas monocline, the Coyote anticline (COA), the La Habra syncline (LHs), and the LA basin central trough. The Los Angeles and San Gabriel Rivers are marked by thin black lines. Compiled from Wright (1991); Schneider et al. (1996); Shaw and Shearer (1999); Dolan and Sieh, et al. (2000); Dolan, Stevens, et al. (2000); Tsutsumi et al. (2001); Meigs and Oskin (2002); Shaw et al. (2002); Myers et al. (2003).

the northern shelf include the Santa Monica-Hollywood fault system and the Newport-Inglewood faults (Dibblee, 1982; Wright, 1991; Dolan and Pratt, 1997; Dolan et al., 1997; Dolan, Sieh, et al., 2000; Dolan, Stevens, et al., 2000; Meigs and Oskin, 2002). Folds associated with blind thrust faults are the Santa Monica Mountains anticlinorium, the Elysian Park anticlinorium (including the MacArthur Park escarpment and the Coyote Pass escarpment), the Montebello Hills (Fig. 2) anticline, and the La Cienegas monocline (Buwalda, 1940; Davis et al., 1989; Wright, 1991; Dolan and Sieh, 1992; Bullard and Lettis, 1993; Schneider et al., 1996; Meigs et al., 1999; Oskin et al., 2000; Weaver and Dolan, 2000; Tsutsumi et al., 2001; Meigs and Oskin, 2002; Meigs et al., 2003). East of the San Gabriel River, the Whittier fault is the major fault that extends to the surface (Rockwell et al., 1992; Bjorklund, 2002; Griffith and Cooke, 2004). Active folds are forming above the Puente
Hills and Coyote Hills blind thrust fault systems, which include the Coyote anticline and La Habra syncline (Yerkes et al., 1965; Yerkes, 1972; Shaw and Shearer, 1999; Shaw et al., 2002; Myers et al., 2003; Griffith and Cooke, 2004).

\section{Rock Uplift Patterns within the Los Angeles Basin}

Folded geologic markers provide evidence of the wavelength, amplitude, and rates of deformation associated with blind thrust fault displacement (e.g., Stein et al., 1988; Shaw et al., 2002; Myers et al., 2003). Rates of shortening, fault slip, and fold growth can be inferred from deformed, dated strata given knowledge about fold shape, fault shape, and inferences about how fault slip is translated into fold growth (e.g., Stein et al., 1988; Hardy and Poblet, 1994; Ford et al., 1997; Suppe et al., 1997; Shaw and Shearer, 1999; Allmendinger and Shaw, 2000). Because blind thrust faults within 
the LA basin have the greatest uncertainty in terms of geometry, connectivity, slip rate, and earthquake potential (e.g., Davis and Namson, 1994; Yeats and Huftile, 1995; Shaw et al., 2002; Griffith and Cooke, 2005), three-dimensional characterization of fault shape must be inferred from fold shape. Whereas kinematic models provide a geometric means for inferring fault shape from folds (e.g., Suppe, 1983; Davis et al., 1989; Woodward et al., 1989; Suppe and Medwedeff, 1990; Shaw and Suppe, 1996), they exclude the mechanics of deformation. Kinematic models satisfy the equations of compatibility but do not satisfy force equilibrium equations, nor do they follow the constitutive laws of deformation. Fault dislocation models, such as the models employed in this study, readily produce both kinematically compatible and mechanically robust uplift fields that can be compared with geodetic and geologic data to determine fault orientation, shape, and slip rate (Stein et al., 1988; Ward and Valensise, 1994; Myers et al., 2003; Savage and Cooke, 2003; Griffith and Cooke, 2004; Savage and Cooke, 2004; Argus et al., 2005).

\section{Rock Uplift Map Construction}

Our objective is a comparative analysis of uplift patterns as determined from geological data and models. To realize this objective, an appropriate datum for measurement of the vertical uplift of structures that underlie the northern shelf must be identified. A geologic marker such as the base of the Pico Member of the Fernando Formation provides such a datum. The Pico Member is nearly ideal because of its continuity throughout the study region, because upper fault tips of blind thrusts occur at depths greater than the base of the unit (Wright, 1991; Schneider et al., 1996; Shaw and Shearer, 1999; Tsutsumi et al., 2001; Shaw et al., 2002; Myers et al., 2003), and because the base of the unit is of a known age and easily identifiable in subsurface data (Myers et al., 2003). Description of absolute uplift rates (or subsidence) would require a different choice of datum (sea level or paleowater depth, for example) because faultrelated folding may produce localized uplift within a region that is otherwise characterized by net subsidence (Seeber and Sorlien, 2000).

Rock uplift and uplift rates were determined in a twostep process (Fig. 1a,b). A series of cross sections was compiled from Santa Monica in the west to the Coyote Hills in the east (Figs. 2 and 3). Each of the sections extends to at least a 3-km depth in the subsurface (Fig. 3). Outcrop data and between 12 and 26 wells constrain the location and structural geometry of folds, stratigraphic thickness, and growth strata geometry across each cross section (see Fig. 3 caption for original references). Subsurface structural relief is represented by the difference between the subsurface depths of the base of the Pico Member within folds relative to the depth at the axis of the central trough (Fig. 1b).

We assume an average depth of $-3000 \mathrm{~m}$ for the conversion of rock uplift from structural relief. Contour maps of rock uplift reflect the difference between depth to the base of the Pico Member on a cross section and $-3000 \mathrm{~m}$ at the axis of the LA trough (Fig. 4a). A contour map of rock uplift rate is based on point values of rock uplift on each cross section divided by $2.9 \mathrm{Ma}$, the age of the base of the Pico Member (Fig. 4b). An age of 2.9 Ma for the base is older than other published ages (Blake, 1991) and is based on a linear interpolation between a dated tuff in near the top of the Repetto Member, a revised age for the Pico Member-San Pedro Formation boundary, and the position of the BruhnesMatuyama paleomagnetic reversal within the San Pedro Formation (Myers et al., 2003). The error in age of the base is $\sim 10 \%$, and the error associated with assuming an average depth for the Pico Member base is $\sim 15 \%$.

Compaction represents a potential source of uncertainty related with measuring rock uplift rate from structural relief of sedimentary strata. The deepest parts of the LA trough may have undergone greater compaction than the flanks of the uplifting anticlines and monoclines, which would result in overestimation of structural relief because the uplift will be underestimated to a greater degree within the basins (e.g., the LA trough) than on the crest of the anticlines. A second source of uncertainty in the rock uplift estimates is the assumption that the base of the Pico Member is the same age everywhere in the LA basin. Well data indicate that strata within the Pico Member thin, rather than onlap, across the limbs and crest of folds (Fig. 3). Although this observation does not guarantee that time, and therefore rock, is not missing across the crests of folds, it does indicate that limited paleorelief existed in the basin at the onset of Pico Member deposition. If significant paleorelief were present, the structural relief may be overestimated; the degree of overestimation will be a proportion of the paleorelief and correspond to the amount of compaction. Whereas these issues may be significant for the rates of rock uplift, in this study we place heavier emphasis on the patterns of uplift. Uncertainties associated with compaction, age, and paleorelief therefore do not affect the overall pattern of uplift associated with growing structures or the comparison with model rates.

The map of rock uplift rate illustrates that the principal structures are the Las Cienegas-Elysian Park anticlinorium in the west and the Coyote Hills-Santa Fe Springs anticlines in the east (Fig. 4) (Schneider et al., 1996; Shaw et al., 2002; Myers et al., 2003). A broad, southwest-sloping structural high separating the Las Cienegas monocline on the southwest from the Elysian Park anticline on the northeast characterizes the Elysian Park anticlinorium (EPA) (Figs. 2, 3, and $4 \mathrm{a}$ ). In the west, the EPA plunges to the west towards the West Beverly Hills lineament (Fig. 2). In the east, the EPA plunges to the east and loses structural relief at the San Gabriel River (Figs. 2 and 3f,g). None of the individual axial traces of the anticlines comprising the EPA extend across the San Gabriel River. Rock uplift across the Las Cienegas monocline are $>1.0 \mathrm{~mm} / \mathrm{yr}$ in the west and $<0.6 \mathrm{~mm} / \mathrm{yr}$ in the east since $2.9 \mathrm{Ma}$ (Fig. 4a). To the southeast, the Coyote Hills-Santa Fe Springs anticlines form a dis- 

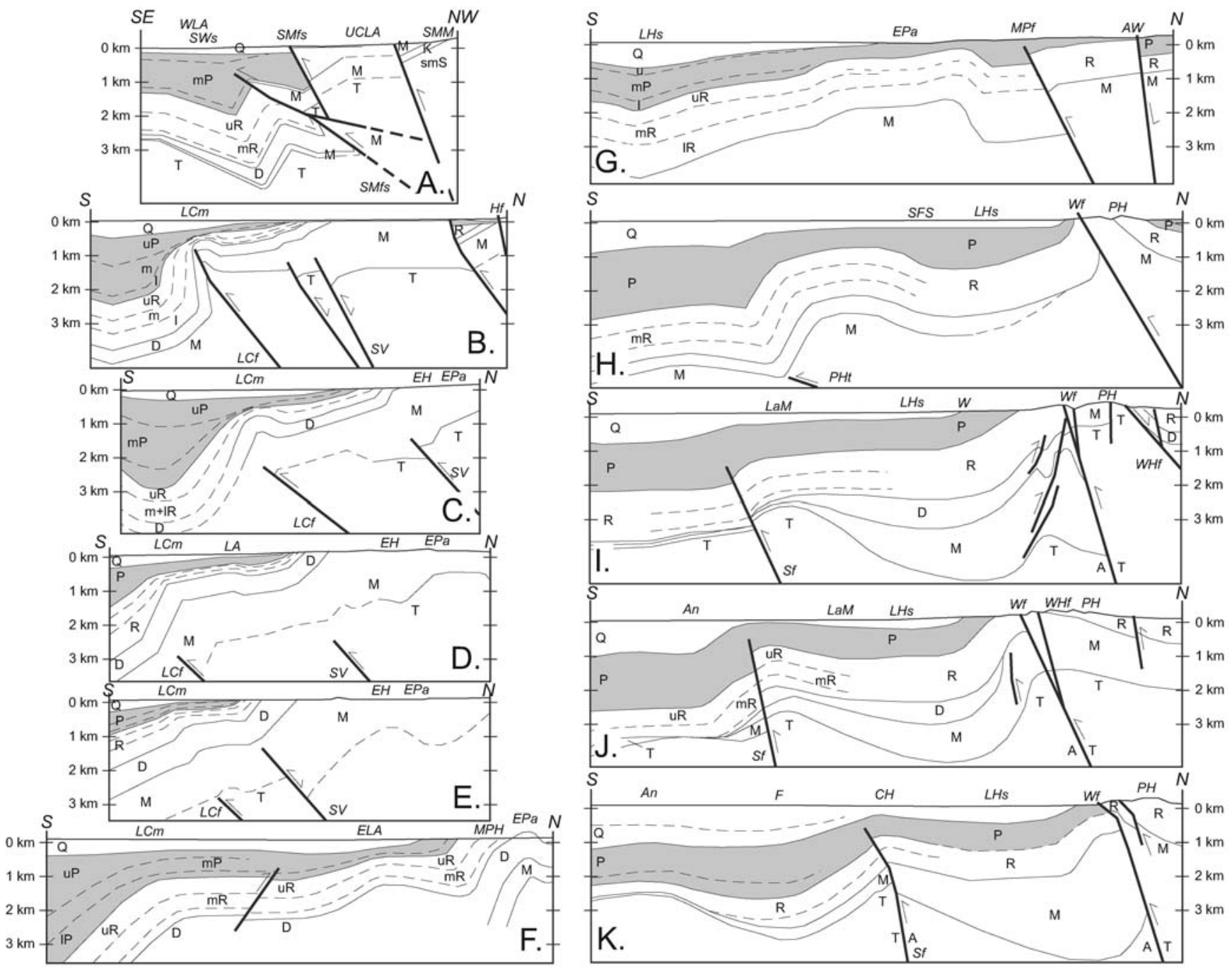

Figure 3. Geological cross sections used to constrain rock uplift and rates (Fig. 4) from west (a) to east (k) along the length of the northern shelf of the LA basin. Pretectonic strata deposited prior to the onset of shortening and after $\sim 5-7 \mathrm{Ma}$ are, from oldest to youngest, the Santa Monica slate (SMS), Cretaceous undifferentiated (K), the Topanga Formation (T), the Puente Formation (M), and Delmontian-aged strata (D). Growth strata deposited during shortening on blind and emergent thrust faults and associated anticlines and monoclines are, from oldest to youngest, the Repetto Member of the Fernando Formation (R), the Pico Member of the Fernando Formation (P), and Quaternary strata undifferentiated (Q). Lower, middle, and upper units of the Repetto and Pico Members are indicated by l, $\mathrm{m}$, and $\mathrm{u}$ where they are differentiated within each unit. Faults are the Santa Monica fault system (SMfs), the Hollywood fault (Hf), the La Cienegas fault (LCf), the San Vincente fault system (SV), the Monterrey Park fault (MPf), the Alhambra Wash (AW), the Whittier fault (Wf), the Workingman Hills fault (WHf), the Puente Hills thrust fault (PHt), and the Stearn fault (Sf). Letters on strike-slip faults indicate lateral motion into the page (Away, A) and out of the page (Toward, T). Folds include the Sawatelle syncline (SWs), the La Ceinegas monocline (LCm), the Elysian Park Anticlinorium (EPa), and the La Habra syncline (LHs). Geographic locations include West Los Angeles (WLA), the University of California, Los Angeles (UCLA), the Santa Monica Mountains (SMM), the Elysian Hills (EH), Los Angeles (LA), East Los Angeles (ELA), Monterrey Park Hills (MPH), Santa Fe Springs (SFS), the Puente Hills (PH), Whittier (W), La Mirada (LAM), the Coyote Hills (CH), and Fullerton (F). cross section used to derive rock uplift and rock uplift rates for the base of the Pico Formation are from: (a)-(c), Tsutsumi et al. (2001); (b)(d), Schneider et al. (1996); (e)-(h), Yeats (unpublished); (i)-(k), Myers et al. (2003).

crete structural high separating the La Habra syncline and Puente Hills on the north from the axis of the LA trough on the south (Figs. 2 and 4a). Contours of rock uplift reveal an arcuate shape to the axial trace of the Coyote Hills anticline, which plunges northwest towards Santa Fe Springs and the San Gabriel River. A continuous anticline between the Coyote Hills and Santa Fe Springs is indicated, although structural relief varies along strike. The structural relief of the anticline has a local minimum at section I with greater relief to the east along the Coyote Hills (Fig. 3j,k) and to the west at Santa Fe Springs (Fig. 3h). Rock uplift rate is greatest in the Coyote Hills ( $>0.5 \mathrm{~mm} / \mathrm{yr}$; Fig. 4a). Whereas the La Habra syncline is a prominent and regionally extensive structure, it is being uplifted with respect to the trough of the LA basin at rates comparable to the Coyote Hills anticline (Figs. 3h-k and 4a). 

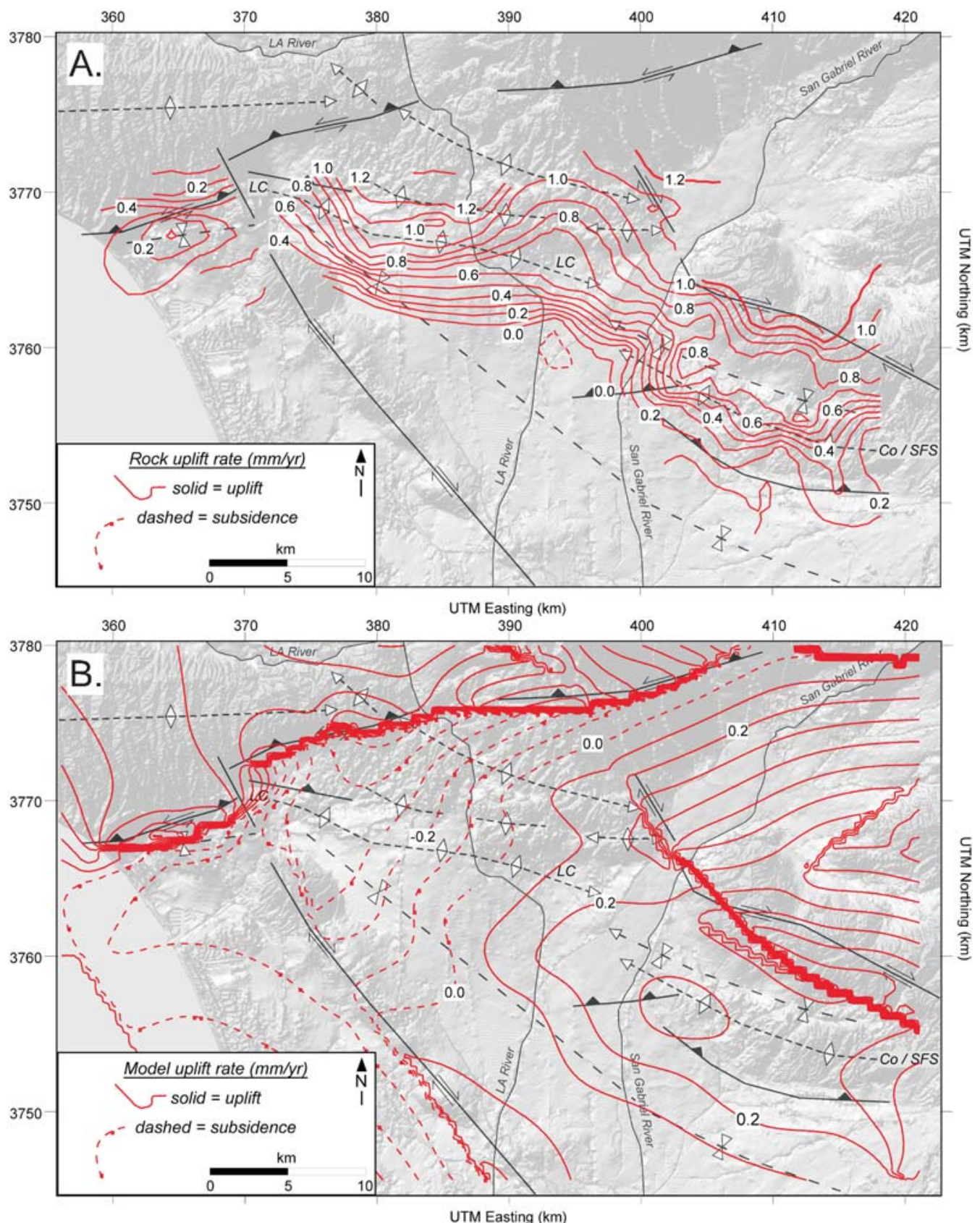

Figure 4. (a) Rock uplift rate inverted from the depth of the base of the Pico Member of the Fernando Formation along the northern shelf of the LA basin. Rock uplift represents the structural relief of the base Pico Member relative to $3000 \mathrm{~m}$ at depth (Fig. 3). Rock uplift rate is the structural relief divided by the age of the unit. The base of the Pico Formation is 2.9 Ma (Myers et al., 2003). Major structures defined in the Figure 2 caption. (b) Uplift and subsidence predicted from BEM of CFM version 2.5 (model 1). The Las Cienegas and Coyote/Santa Fe Springs monocline and anticline are indicated by LC and CO/SFS, respectively.

\section{Three-Dimensional Fault Model of the Los Angeles Basin}

\section{Southern California Earthquake Center Community Fault Model}

The CFM is a database of potentially seismogenic faults across the seismogenic crust of southern California using the best available information on the location, dip, and along- strike continuity. The fault surfaces are represented within the CFM as triangular tessellated surfaces to preserve the nonplanar surfaces and irregular fault intersections inferred in the subsurface. Faults within the CFM extend to the local base of seismicity at roughly $18 \mathrm{~km}$ (Plesch et al., 2002). Fault representation uncertainty in the CFM is a function of the strength of the available constraints (e.g., seismic lines and seismicity) on location and orientation (Plesch et al., 
2002). A high confidence level is assigned to faults constrained by direct observation, and a lower level of confidence is given to faults inferred from models or other sources. Alternative fault configurations are ranked according to preference of workers in the region. For this study, we explore the preferred fault configuration of the CFM version 2.5 and several alternatives (Fig. 5). We focus on the blind fault system underlying the northern shelf of the LA basin in the region bounded on the west by the NewportInglewood fault, in the north by the Santa Monica, Hollywood, and Raymond faults, on the east by the eastern end of the Coyote segment of the Puente Hills thrust system, and on the south by the central trough of the LA ba$\sin$ (Fig. 2).

\section{Three-Dimensional Boundary-Element} Method Models

The boundary-element method (BEM) is well suited for the investigation of three-dimensional active faulting because this method accurately simulates deformation associated with sliding cracks within an elastic continuum (e.g., Thomas, 1994; Crider and Pollard, 1998) Unlike other continuum mechanics methods like finite element methods that discretize the volumes around faults, the BEM requires discretization of only the fault surfaces. This enables BEM models to represent complex fault systems with fewer elements and fewer three-dimensional meshing challenges. For this study, we use the BEM code, POLY3D, developed by researchers at Stanford University (Thomas, 1994) and the Igeoss Corporation (www.igeoss.com). The triangular elements that POLY3D uses to discretize fault surfaces permit the accurate representation of the nonplanar and nonrectangular CFM faults (Griffith and Cooke, 2004, 2005; Cooke and Marshall, 2006). Whereas previous studies of southern California have used BEM models to investigate slip sense and tectonic boundary conditions (e.g., Griffith and Cooke 2004, 2005), fault propagation (Olson and Cooke, 2005), and geologic fault slip rates (e.g., Cooke and Marshall, 2006), here we use BEM models to predict locations of uplift and subsidence and compare results to an independent geologic data set.

The modeled CFM faults freely slip in response to both the applied tectonic boundary conditions and interaction with nearby faults. We apply 72 nanostrain per year of contraction at $\mathrm{N} 09^{\circ} \mathrm{E}$ and 0 nanostrain per year contraction at $\mathrm{S} 81^{\circ} \mathrm{E}$ according to present-day geodetic velocities (Argus et al., 2005). Within three-dimensional models, these tectonic boundary conditions produce fault slip senses that match expected slip sense (Griffith and Cooke, 2005) and slip rates that match the available geologic slip rates (Cooke and Marshall, 2006). Present-day tectonic boundary conditions may not have persisted over the 2.9 Ma following the beginning of deposition of the Pico Member and younger strata. Since 2.9 Ma, the San Gabriel block has rotated about $\sim 18^{\circ}$ degrees counterclockwise (Molnar and Gipson, 1994;
Nicholson et al., 1994), strike-slip displacement along faults such as the Newport-Inglewood and Whittier faults may have increased (Wright, 1991; Bjorklund, 2002), and growth has been initiated on the Coyote and Santa Fe Springs anticlines (Shaw et al., 2002; Myers et al., 2003). Growth of the Elysian Park anticlinorium, including the Las Cienegas monocline, was initiated after $\sim 5 \mathrm{Ma}$ and persists to the present (Wright, 1991; Schneider et al., 1996; Meigs and Oskin, 2002; Meigs et al., 2003). Therefore, the CFM structures incorporated into the BEM models were faults active over the time frame beginning with deposition of the Pico Member.

The LA basin fault network of the CFM version 2.5 is used as boundaries within the mechanical model. Fault surface meshes of the CFM are adjusted so that element size is roughly constant in order to prevent numerical artifacts. For similar reasons, every fault intersection is adjusted so that the elements intersect at coincident nodes to insure compatibility of the resulting slip distribution. The model of the LA region uses over 5200 elements to simulate 34 faults within an average element diameter of $3 \mathrm{~km}$. Most fault intersections within the upper $18 \mathrm{~km}$ were maintained in the model; however, a few minor faults were altered to abut against others to reduce inordinate complexity and improve stability of the model.

To simulate geologic deformation throughout the seismogenic crust, we extend the CFM faults from the base of seismicity to a depth of $27.5 \mathrm{~km}$ where they sole into a freely slipping horizontal detachment. This detachment sits at the inferred depth of the Moho imaged in Los Angeles region seismic experiment 1 (LARSE I; Fuis et al., 2001) and is within the range of Moho depths inferred from seismic velocity modeling of the region (Magistrale et al., 2000). The fault surfaces between 18 and $27.5 \mathrm{~km}$ simulate the lower crustal deformation that occurs within geologic times scales and yields more accurate surface geologic uplift rates. Major faults that intersect below $18 \mathrm{~km}$ were permitted to intersect each other, but minor faults were assumed to abut into major faults below $18 \mathrm{~km}$. For example, the LA fault and the Verdugo/Eagle Rock faults abut the Lower Elysian Park fault at $\sim 21 \mathrm{~km}$ depth. The Puente Hills fault is soft linked to the Lower Elysian Park fault because the small interfault angle led to geometric instabilities within the model. This fault geometry was shown by Cooke and Marshall (2006) to match well the geologic slip rates on the faults of the LA basin.

The modeled faults are embedded within a linear-elastic half-space with Young's modulus of $30 \mathrm{GPa}$ and Poisson's ratio of 0.25 ; these values represent properties between the values for basement and the values for young sedimentary material (Birch, 1966). If the models were to include the effects of heterogeneous compliant sedimentary fill within the LA trough, the resulting uplift patterns might differ; we expect the applied contraction would produce greater fault slip within the stiffer basement rocks than within the more compliant sedimentary rocks. Lesser slip within the near-surface sediments might diffuse the local expression of geologic uplift from the model results presented here. An implicit as- 

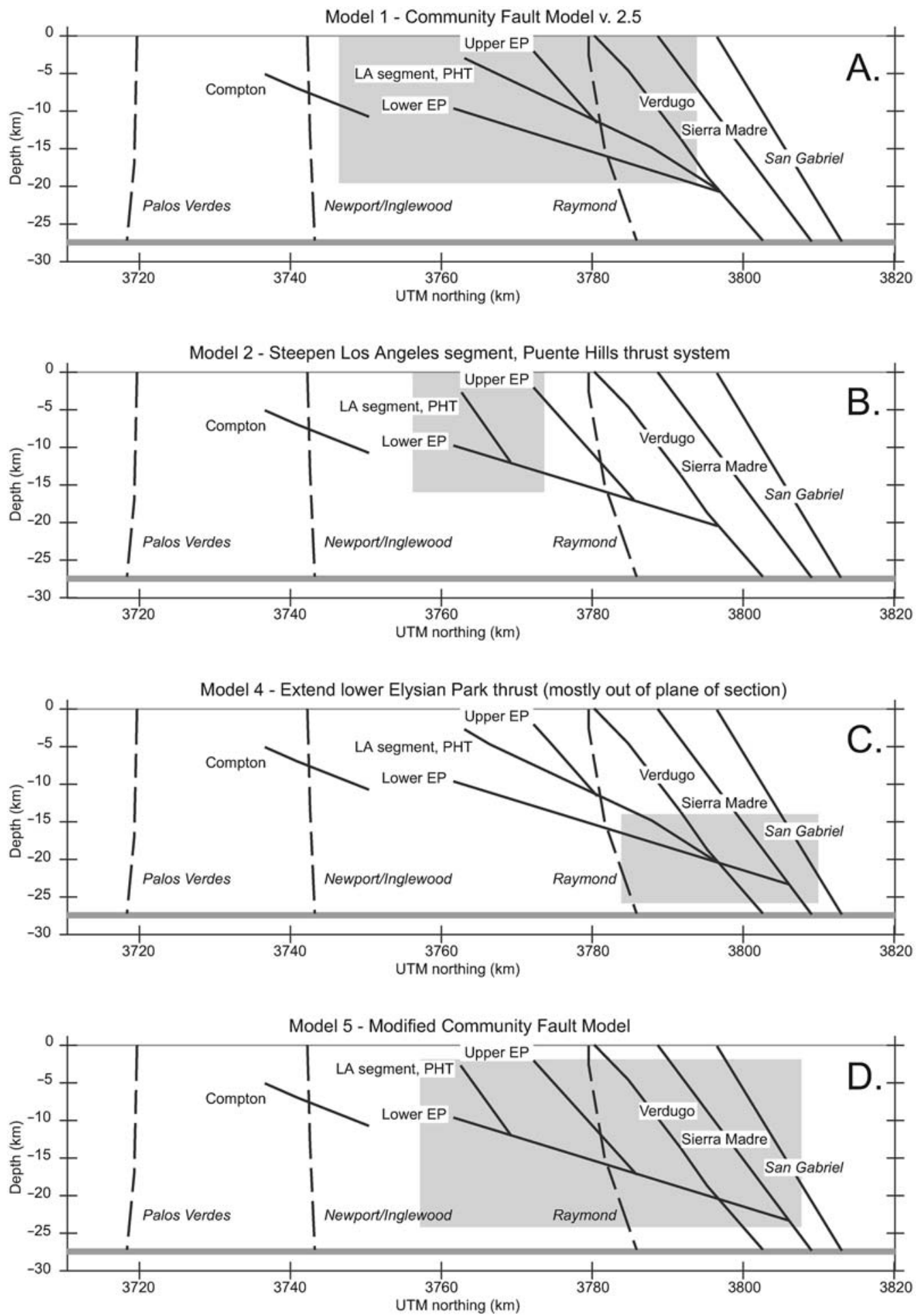

Figure 5. Model cross sections. (a) The CFM (model 1). (b)-(d) Alternative models (models 2, 4, and 5). Model 3 tests along-strike connectivity of the Raymond-Hollywood faults and is not depicted in cross section here. Cross sections are oriented north-south at universal transverse mercator (UTM) Easting km 394, between cross sections E and F (Fig. 2, bold black line). (b) Model 2 incorporates a steep LA segment of the Puente Hills thrust fault following interpretations for the Las Cienegas fault. (c) Model 4 laterally lengthens the Lower Elysian Park thrust fault along strike to the northwest. Because of the oblique direction of this section, the continuation of the fault appears as a relatively small down-dip segment. (d) Model 5 shows the cross section with all modifications including the removal of a link between the Raymond and Hollywood faults, which is not shown in this plane of section. Dashed lines show right-lateral faults. Shaded areas highlight regions with fault modifications. 
sumption in our approach is that loci of uplift and subsidence produced by the elastic model are a proxy for regions of uplift and subsidence revealed by the structural and stratigraphic data. Whereas the deformation within elastic models is recoverable, geologic materials accumulate permanent strains via distributed inelastic processes such as microcracking, grain boundary sliding, and calcite twinning. These inelastic processes are not simulated in our models, but the distribution of inelastic deformation should mimic the elastic stress field; for example, greatest microcracking occurs where stresses are greatest. Elastic deformation acquired on short time scales (i.e., slip on fault in an earthquake) can be accommodated by inelastic processes, which would preserve strain and dissipate stresses over longer time scales. Thus, the pattern of uplift within our elastic models approximates the first-order deformation of geologic materials, including inelastic processes.

The absolute rates of model uplift are expected to be significantly less than those inferred from the geologic data because the modeled faults are embedded in an unlayered linear-elastic half-space. This half-space formulation does not incorporate inelastic flexural slip along bedding planes that act to tighten and increase amplitude of folds (e.g., Erickson, 1996; Johnson and Johnson, 2000; Savage and Cooke, 2003), thereby increasing local uplift rates. The strong tendency for flexural slip to enhance folding may, in many settings, overwhelm the diffusing effect of nearsurface soft sediments. Although the amplitude of model and geologic uplift may not be matched, the pattern of folding can be matched with half-space models (e.g., Savage and Cooke, 2004). The critical comparison, from the point of view of exploring fault geometries that best fit the data, is between the geologically constrained pattern of uplift and subsidence associated with major structures and the patterns arising from three-dimensional models.

\section{Comparison of Model and Geologic Uplift Rate Patterns}

Model-data compatibility was evaluated on the basis of structural trend, spatial variation in rates, and location of major structures (i.e., near-surface folds). Whereas the geological cross sections capture the structural details, BEM models produce regions of uplift and subsidence that are controlled by fault geometry, connectivity, interaction of closely spaced faults, and contraction rate. It is unreasonable, therefore, to expect that the BEM models will match the geological data on the scale of the fine details of the structures. Furthermore, uncertainties associated with compaction, age, and paleorelief may influence the details of the geologic structural relief. Regions of uplift and subsidence produced by BEM models should, however, capture the major regions of geologic uplift and subsidence. A key feature, for example, that should result from the models is the central trough of the LA basin (Fig. 2). To the east of the San Gabriel River, models are expected to accurately mimic the location and extent of the structural highs associated with the Coyote and Santa Fe Springs anticlines and the structural low represented by the La Habra syncline. West of the San Gabriel River, the EPA, including the Las Cienegas monocline, extends to the Newport-Inglewood fault (Fig. 2) and has greater structural relief than the Santa Fe and Coyote anticlines. Cross sections $\mathrm{C}, \mathrm{F}$, and $\mathrm{H}$, which depict the major structures to the west and east of the San Gabriel River, respectively, are used to highlight data-model compatibility (Figs. 2 and 6-8)

\section{Model 1: CFM Version 2.5}

Fit between CFM-based model uplift and observed folds is good to the east of the San Gabriel River (Fig. 4). For example, the uplift pattern from the CFM model matches well the location and trend of the Coyote Hills and Santa Fe Springs anticlines and the orientation of the central LA trough (Fig. 4). Structural trends of these anticlines in the model changes from west- to northwest-trending along strike towards Santa Fe Springs, which is consistent with the trend of the folds in the subsurface and associated topography at the surface. A structural low in the model to the north of the anticlinal uplift (Fig. 6) mimics the location of the La Habra syncline. Uplift of the La Habra syncline relative to the central trough is produced by the model as well. Model-data compatibility to the east of the San Gabriel River, therefore, is good and suggests that the CFM in this region is compatible with the observed fold structures. This result is particularly important because the Puente Hills thrust is well constrained in the region of Santa Fe Springs by industry seismic data in the upper crust and by the hypocentral location of the Whittier Narrows earthquake mainshock (Shaw et al., 2002).

A comparison of model and data to the west of the San Gabriel River, in contrast, indicates that patterns of uplift from the BEM models of the CFM do not match geologically constrained locations and orientations of major folds. In the region south of the Hollywood fault and east of the NewportInglewood fault, the model predicts that subsidence dominates the vertical motion (Fig. 4). Geologically, this region marks the crest of the Elysian Park anticlinorium between the Las Cienegas monocline on the south and the Elysian Park anticline on the northeast (Figs. 3b-d and 4a). However, within the model, subsidence is produced over much of the area between the San Gabriel River and the NewportInglewood fault (Fig. 4b). Whereas the Elysian Park anticlinorium dominates the surface and subsurface deformation (Figs. 3b-f and 4a), the CFM-based model fails to produce uplift in this region (Fig. 4b). Improvement of the match between the model and geologic uplift patterns west of the San Gabriel River thus requires testing alternatives to the CFM fault configuration.

A variety of characteristics of the fold and fold architecture of the northern shelf suggest alternative fault models. In addition to our primary model, a suite of models that investigates varying characteristics of three fault systems of the 


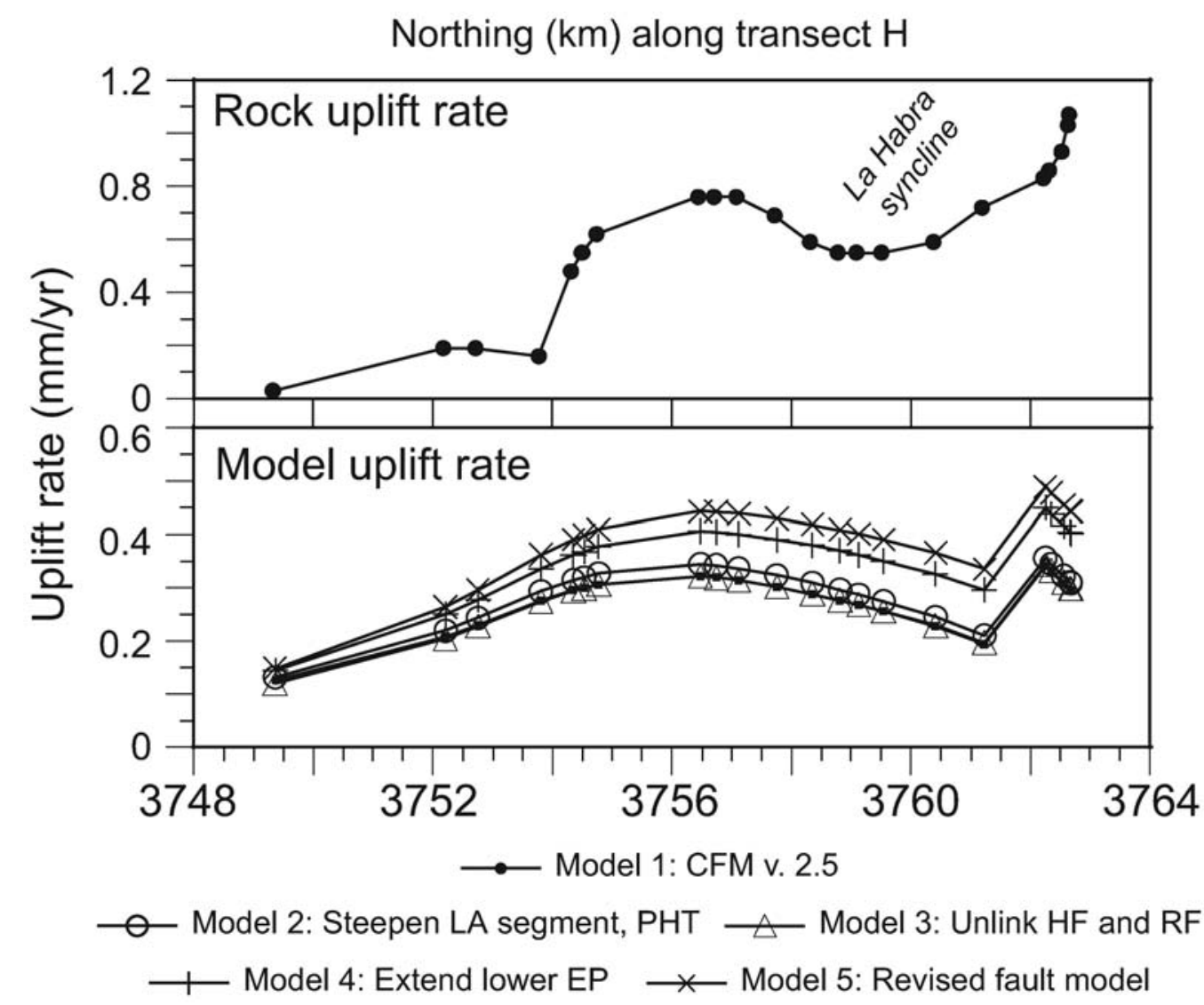

Figure 6. Plots of geologic rock uplift rate (top) and CFM-based and alternative model results along transect $\mathrm{H}$ across the Puente Hills anticline (bottom). Individual alternative models include steepening the LA fault to match dip of the Las Cienegas fault (model 2), disconnecting the Raymond from the Hollywood faults (model 3), and lengthening the Lower Elysian Park ramp (model 4). Model 5 incorporates all alternative fault configurations tested in models 2-4. See Figure 2 for location.

CFM: model 2, the LA segment of the Puente Hills blind thrust fault; model 3, a low-angle detachment below these faults (the Lower Elysian Park thrust (Davis et al., 1989); and model 4, the Hollywood and Raymond faults (Fig. 5). All other CFM faults are unchanged in models 2-4. The objective in testing alternative models is to create patterns of uplift that more closely mimic the location, trend, and relative rate of uplift as recorded by the observed folds. Changes in fault dip, lateral extent, and connectivity based on surface and subsurface data will affect model uplift patterns and thereby potentially decrease the mismatch between models and data. Variability of a single parameter (e.g., fault dip) for a given fault is tested in each alternative model (models 24; Figs. 7 and 8). A fifth model data comparison includes all the modified fault geometries (model 5; Figs. 8 and 9).

Two transects are used to assess the effects of varying fault geometry on patterns of uplift and uplift rate west of the San Gabriel River. Transect $C$ represents the fold structure in the west near the Newport-Inglewood fault (Figs. 2 and 3c). Major features of the structure on transect $\mathrm{C}$ are the central trough and northern shelf structures, including the Las Cienegas monocline, and the crest of the Las Cienegas monocline (Fig. 4a). Transect F, which is parallel to and immediately west of the San Gabriel River (Figs. 2 and 3f), shows a geologic structure characterized by a step-like profile where structural relief and uplift rate change rapidly across the Las Cienegas monocline, gradually across the crest of the Las Cienegas monocline, and rapidly across the eastern Elysian Park anticline from south to north, respectively (Fig. 3f).

Model 2: Steepen the Los Angeles Segment of the Puente Hills Thrust System

Dip and location of the LA segment of the Puente Hills thrust (PHT) system in the CFM have been interpreted from geometric-kinematic models based on growth strata geometry observed in seismic lines (Plesch et al., 2002; Shaw et al., 2002) and has been assigned a $27^{\circ} \mathrm{dip}$ (Fig. 5). The upper tip of the LA segment of the PHT as proposed by Shaw et al. (2002) follows the trace of the Las Cienegas monocline and fault mapped by Schneider et al. (1996) and Wright (1991). Direct observation of the fault dip at depth is provided by well data, which intersect a fault that dips $60^{\circ}$ to a 4-km depth (referred to as the Las Cienegas fault) (Schnei- 


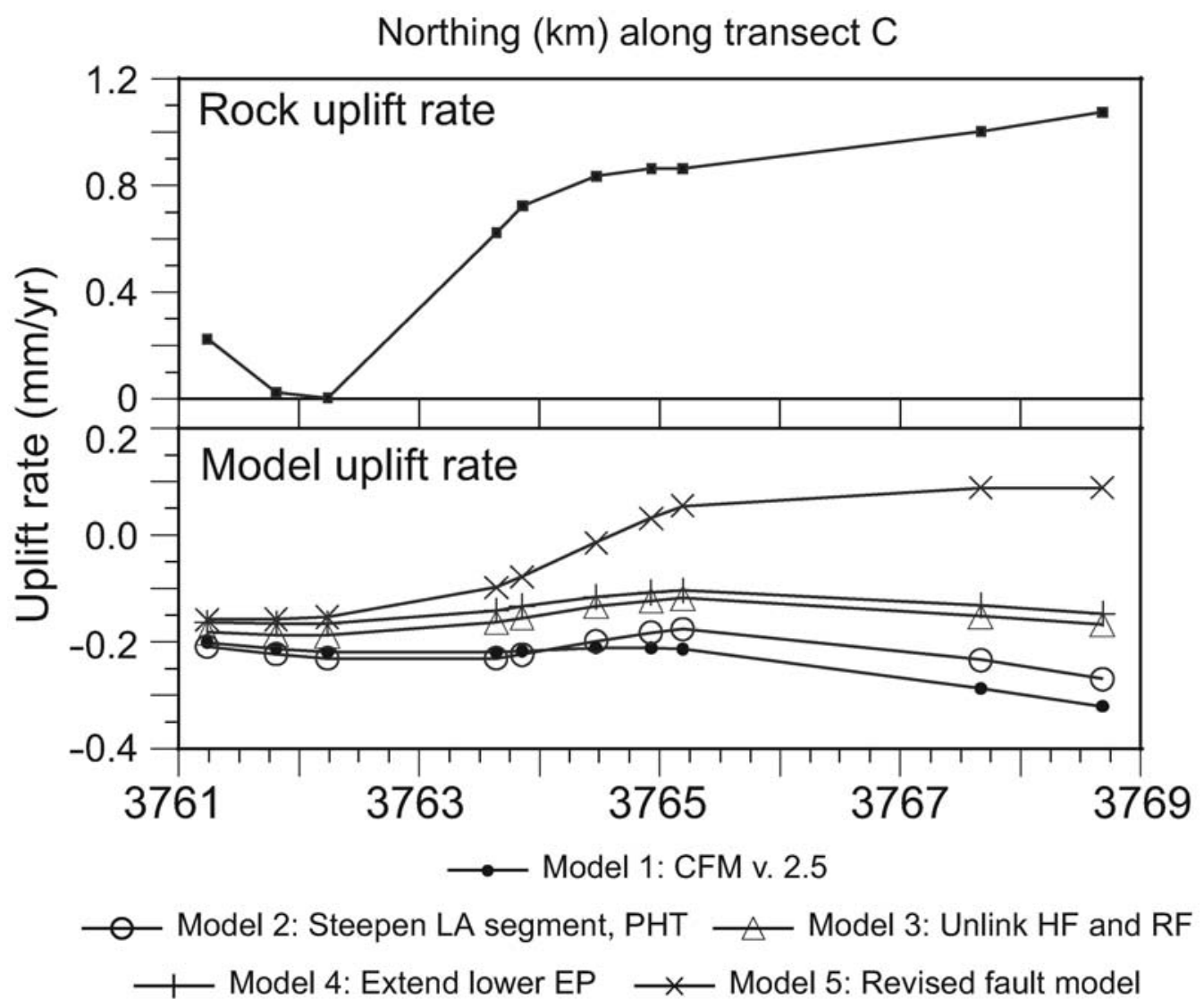

Figure 7. Plots of geological rock uplift rate (top) and model results from the CFM and variations on the CFM along transect C (bottom). Individual alternative models include steepening the LA fault to match dip of the Las Cienegas fault (model 2), disconnecting the Raymond from the Hollywood faults (model 3), and lengthening the Lower Elysian Park ramp (model 4). Model 5 incorporates all alternative fault configurations tested in models $2-4$. The preferred model that matches best the shape of the Las Cienegas monocline is the model with all three modifications (model 5). See Figure 2 for location.

der et al., 1996). If the Las Cienegas monocline is the up-dip expression of the Las Cienegas fault at depth, the continuity of the monocline is a proxy for the fault location from the Newport-Inglewood fault to the San Gabriel River (Fig. 3b-f). Steepening the LA segment in the CFM to $60^{\circ}$ is therefore equivalent to extending the Las Cienegas fault along-strike, which, in the CFM, is restricted to a short segment in the northwest portion of the Los Cienegas monocline trend (Fig. 1).

Changing the geometry of the LA fault segment increases model uplift rates, but fails to approximate the major fold shapes. Steepening the LA segment of the Puente Hills thrust fault in the model increases the amplitude of the overlying Las Cienegas monocline in both transects $\mathrm{C}$ and $\mathrm{F}$ because reverse slip along the steeper fault produces a greater component of vertical displacement than the shallower dipping fault of model 1. In the region of the western transect (C, Fig. 7), the increase in uplift in the north associated with a steeper LA segment produces a closer match to the data. Within the eastern transect (F, Fig. 8), however, a steep fault increases the amplitude of the monocline, but also amplifies the relief of the monocline relative to a syncline in the north, which reduces model-data compatibility. The increased amplitude of the hanging wall syncline in transect $F$ may be an effect of interaction between the steeper LA segment and the Upper Elysian Park fault.

Model 3: Link/Unlink Raymond and Hollywood Fault Systems

Fault intersection and linkage fundamentally impact the displacement field in BEM models (Griffith and Cooke, 2004). Fault linkage has been suggested between the Hollywood and Raymond faults (Weaver and Dolan, 2000), which are important faults because they bound the northern edge of the LA basin. The Hollywood fault is expressed geomorphically and geologically on the south flank of the eastern Santa Monica Mountains (Dolan, Stevens, et al., 2000; Meigs and Oskin, 2002). The fault can be traced laterally from the West Beverly Hills lineament in the west to the Los Angeles River in the east (Fig. 2). Similarly, the Raymond fault is clearly identifiable on the north flank of the San Gabriel basin (Buwalda, 1940; Weaver and Dolan, 2000). Whereas the northeastern end of the fault intersects the Sierra Madre fault 


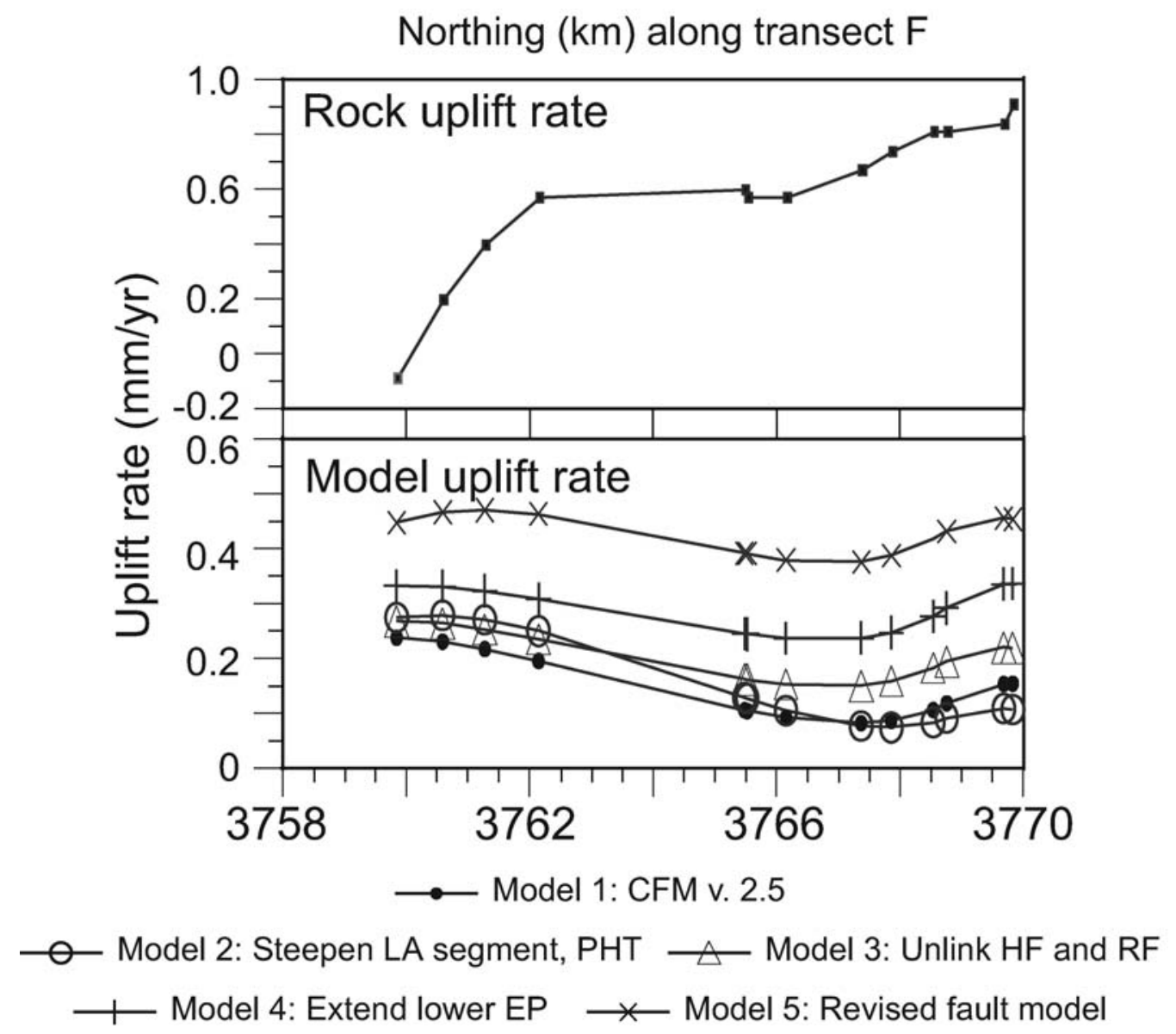

Figure 8. Plots of geologic rock uplift rate (top) and model results from the CFM and variations on the CFM along transect F (bottom). Individual alternative models include steepening the LA fault to match dip of the Las Cienegas fault (model 2), lengthening the Lower Elysian Park ramp (model 3), and disconnecting the Raymond from the Hollywood faults (model 4). Model 5 incorporates all alternative fault configurations tested in models 2-4. The preferred model that matches best the shape of the Las Cienegas monocline and the Elysian Park anticline is the model with all three modifications. See Figure 2 for location.

(Crook et al., 1987), its southwestern end is uncertain (Weaver and Dolan, 2000). Despite the fact that both the Raymond and Hollywood faults project laterally along-strike towards the Los Angeles River, there is no through-going fault trace at the surface to indicate they are different strands of the same fault system (Dibblee, 1989, 1991).

Model 3 was constructed with no connection along strike (unlinked) between the Raymond and Hollywood faults (Fig. 5). Uplift across the crest of the Las Cienegas monocline is higher than that for model 1 and better matches the geologic pattern across the western transect $\mathrm{C}$ in the unlinked model (Fig. 7b). The model-created syncline in the hanging wall of the LA segment has lower amplitude when the link between the Raymond and Hollywood faults is removed. The resultant fold shape more closely resembles a monocline than it does an anticline-syncline pair. Increases in structural relief between the Las Cienegas monocline crest and the Elysian Park anticline are seen on the eastern transect (F, Fig. 8b). Although uplift rate across the crest of the Las Cienegas monocline is effectively unchanged from model 1 , an increased uplift rate on the northern end of transect $F$ has the effect of increasing the differential relief between the northern region of the model and points to the south. As a result of the increase in rate on the north, the uplift pattern more closely mimics the observed fold geometry.

Removing the link between the Raymond and Hollywood faults increases average reverse slip along the Upper Elysian Park fault from 0.3 to $0.4 \mathrm{~mm} / \mathrm{yr}$, which subsequently increases the amplitude of the overlying Elysian Park anticline. Furthermore, average reverse slip along the Hollywood and Raymond faults is reduced from 0.7 to $0.4 \mathrm{~mm} /$ $\mathrm{yr}$, respectively. These reductions, along with removal of the link, which has $1.0 \mathrm{~mm} / \mathrm{yr}$ reverse slip in model 1 (the CFM), transfer a greater proportion of contraction to the hanging walls of the Upper Elysian Park and Puente Hills Thrust faults.

\section{Model 4: Extend Lower Elysian Park Thrust}

In model 4, the Lower Elysian Park thrust is continued along strike to the northwest to test the impact of a laterally 

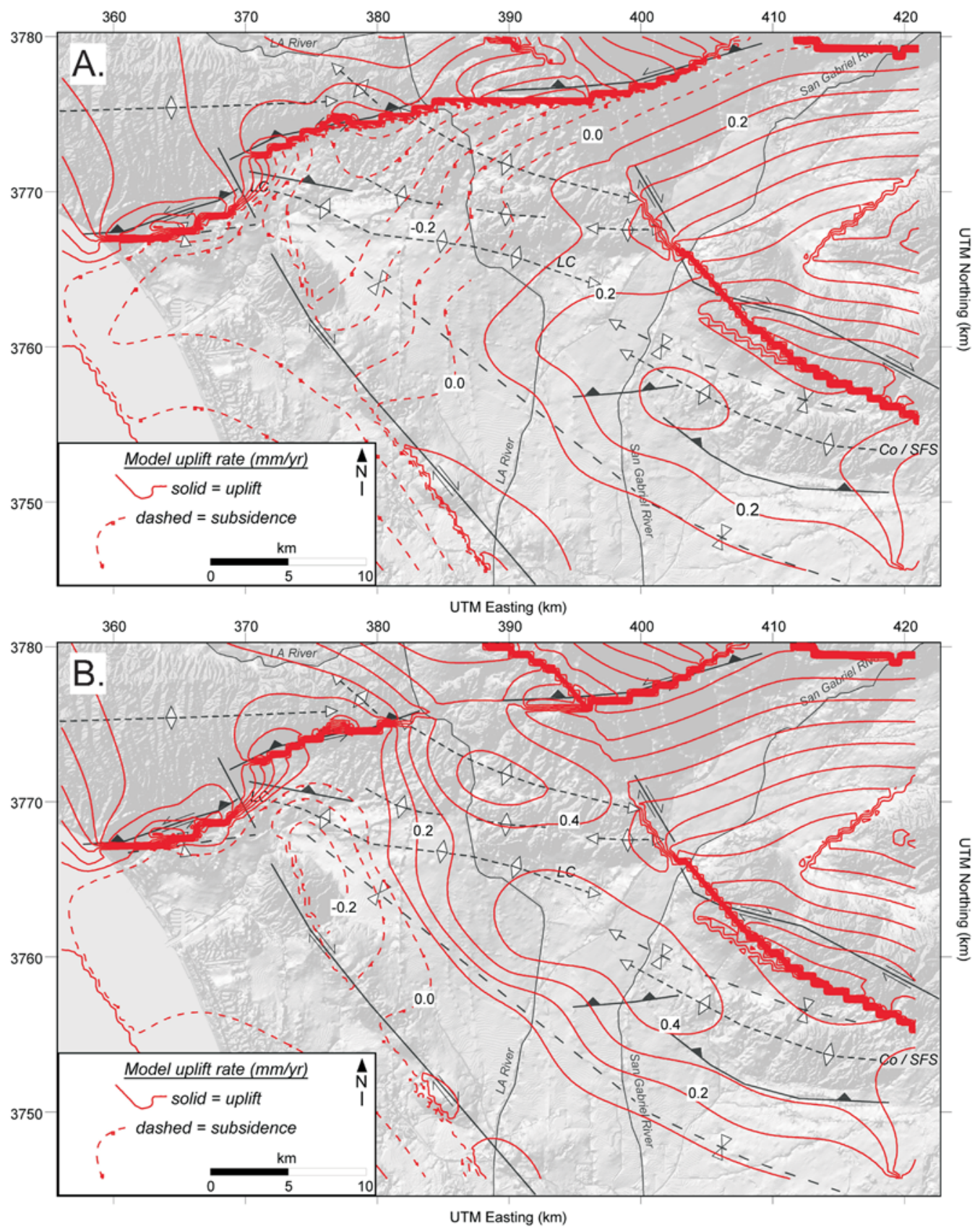

Figure 9. Maps of rock uplift rate for (a) the CFM (model 1) and (b) the preferred model 5, which includes steepening the LA fault to match the dip of the Las Cienegas fault, extending the Lower Elysian Park ramp, and disconnecting the Raymond from the Hollywood faults. Major structures defined in Figure. 2 caption. The Las Cienegas and Coyote/Sante Fe Springs monocline and anticline are indicated by LC and $\mathrm{CO} / \mathrm{SFS}$, respectively.

extensive deep ramp on the uplift field. The extended portion of the Lower Elysian Park low-angle detachment intersects the Verdugo, Hollywood, Santa Monica, and Sierra Madre West faults providing greater fault connectivity to the model. The CFM and other models of the fault structure of the LA basin hypothesize the existence of the Lower Elysian Park thrust, a deep north-dipping blind fault (extending from a depth of $10 \mathrm{~km}$ on the south to $>20 \mathrm{~km}$ below the Puente Hills thrust system (Fig. 5a). Originally inferred from geometric-kinematic models of the Elysian Park anticlinorium (Davis et al., 1989), the Lower Elysian Park thrust has been invoked to explain a syncline in the footwall of the Santa Fe Springs segment of the Puente Hills thrust (Shaw and Shearer, 1999; Shaw et al., 2002). According to the CFM, therefore, the fault system under metro LA is a stack of shallowly north-dipping thrust sheets. The Lower Elysian Park fault dips $\sim 20^{\circ}$ to the northeast and is located structurally beneath the $\sim 27^{\circ}$ northeast-dipping Puente Hills thrust sys- 
tem (Shaw et al., 2002). An alternative to this structural architecture is suggested by results from the LARSE I geophysical experiment (Fuis et al., 2001). The crustal scale cross section suggested by the LARSE I data consists of a single north-dipping ramp at depth beneath LA. Blind and emergent faults in the LA basin are interpreted to root into this décollement (Fuis et al., 2001). The crustal structure across the eastern Santa Monica Mountains, the Verdugo Mountains, and the southern San Gabriel Mountains is consistent with a model of crustal structure consisting of a single master ramp at depth (Meigs et al., 2003).

Unlinking the Raymond and Hollywood faults and extending the Lower Elysian Park thrust have similar effects on the form of the uplift rate across the two transects (Figs. 7 and 9). Extending the Lower Elysian Park fault nearly doubles the model uplift rate from CFM values for both transects $\mathrm{C}$ and $\mathrm{F}$ (Figs. 8 and 9). A clear monoclinal form results from extending the Lower Elysian Park thrust to the northwest (Fig. 7b). Lateral extension of the Lower Elysian Park fault to the region of transect F (Fig. 8) increases the uplift rate gradient and structural relief, which represents a better match to the geologic data across the Las Cienegas monocline crest and the Elysian Park anticline. Whereas the form of the model uplift pattern mimics well the crest of the Las Cienegas monocline and the south limb of the Elysian Park anticline, the southern limb of the Las Cienegas monocline in this and the other models is farther south than in the geologic data (Fig. 7b). Mismatch between the model and observed fold limb location may reflect poor control on the fault location. Alternatively, flexural slip within the strata overlying the Las Cienegas fault would tighten the hanging wall fold and shift the monoclinal limb slightly to the north thereby explaining the mismatch.

Extending the Lower Elysian Park thrust enhances the connectivity of faults within the model, which increases reverse slip along the Lower Elysian Park, Upper Elysian Park, Hollywood, and Raymond faults. Average reverse slip along the Lower Elysian Park fault increases from 0.6 to $0.8 \mathrm{~mm} / \mathrm{yr}$, and reverse slip rates along the Upper Elysian Park, Hollywood and Raymond faults increases by 0.07 , 0.2 , and $0.1 \mathrm{~mm} / \mathrm{yr}$, respectively. Increased reverse slip along the upper Elysian Park fault serves to amplify the development of the Elysian Park monocline whereas increased reverse slip on the deep Lower Elysian Park fault has the effect of increased uplift over the broad region represented within transects $\mathrm{C}$ and $\mathrm{F}$.

\section{Model 5: An Alternative CFM}

An alternate CFM (model 5) includes (1) a steep LA segment of the Puente Hills thrust, (2) unlinked Raymond and Hollywood faults, and (3) a Lower Elysian Park thrust that extends from the San Gabriel River to the northwest under the Santa Monica Mountains, which results in uplift rates and a pattern of uplift that departs from that of the CFM model and approaches that of the geologically defined folds
(Figs. 7-9). Marked improvement in model-data compatibility is seen in both map and cross-section views (Figs. 7-9). A clearly defined northwest-trending region of subsidence is localized to the east of the Newport-Inglewood fault, which coincides well with the location of the central trough of the LA basin (Fig. 2). Some features of the Elysian Park anticlinorium are more clearly expressed in the composite model. A doubly plunging west-northwest-trending region of uplift, for example, develops to the south of the Raymond and Hollywood faults at the location of the Elysian Park anticline (Figs. 2, 5, and 9). Discrete anticlinal crests are created in the region of the Las Cienegas monocline on the south and the Elysian Park anticline on the north. The model well describes the monoclinal form of the geologic structure in the region of transect $\mathrm{C}$ in the west (Fig. 7). To the east, along transect $\mathrm{F}$, the measured uplift rate increases uniformly from the monocline northward, whereas the model uplift rate decreases and then increases from south to north (Fig. 8). Uplift in the region of the Santa $\mathrm{Fe}$ and Coyote segments of the Puente Hills thrust system is higher and more laterally extensive in model 5 than in the CFM (model 1). Uplift rates from model 5 more closely approximate geologic rates, although the fit in the east on transect $\mathrm{F}$ is better than in the west on transect $\mathrm{C}$ (compare Figs. 7 and 8). Whereas the alternate fault geometries of model 5 do not affect the pattern of uplift above the Santa Fe Springs thrust, they do cause an overall increase in uplift rate (Fig. 6).

\section{Discussion}

The sensitivity of uplift pattern to alterations in subsurface fault configuration within the LA basin reveals the influence of fault connectivity and fault area on fault slip rates. Steepening the LA segment of the Puente Hills thrust fault so that it soles into the Lower Elysian Park fault, as in the preferred model (model 5; Fig. 5), decreases fault surface area of the LA segment dramatically from 795 to $268 \mathrm{~km}^{2}$. Because the fault is smaller and steeper, we should expect a decrease in slip rate along the steeper LA segment of the Puente Hills thrust fault. Smaller faults generally slip at slower rates than larger faults. Furthermore, isolated $60^{\circ}$-dipping faults are less favorably oriented for slip under horizontal contraction than $30^{\circ}$-dipping faults. Whereas we expect slower slip rates, the average reverse slip rate along the LA segment increases from 0.5 to $0.6 \mathrm{~mm} / \mathrm{yr}$ between the CFM (model 1) and model 5. Fault slip and associated uplift are thus more strongly influenced by the connectivity of the faults than by fault dip and fault area.

Cooke and Marshall (2006) show that fault slip rates from three-dimensional mechanical models using the CFM version 2.5 match well the geologic and paleoseismic slip rates on most faults of the LA basin. The alterations to the fault geometry within the preferred model presented here may affect the match to available geologic slip rate data. Faults that change by $0.2 \mathrm{~mm} / \mathrm{yr}$ or more in average reverse or strike-slip rates from model 1 to the preferred model 5 are 
Table 1

Average Fault Slip Rates for the Los Angeles Basin (Working Group of California Earthquake Probabilities [WGCEP], 2006)

\begin{tabular}{|c|c|c|c|c|c|c|c|c|}
\hline \multirow[b]{2}{*}{ Fault } & \multicolumn{2}{|c|}{ Geologic Rates } & \multicolumn{3}{|c|}{ CFM Model } & \multicolumn{3}{|c|}{ Preferred Model } \\
\hline & $\begin{array}{r}\text { Reverse Slip } \\
(\mathrm{mm} / \mathrm{yr})\end{array}$ & $\begin{array}{c}\text { Left-Lateral Slip } \\
(\mathrm{mm} / \mathrm{yr})\end{array}$ & $\begin{array}{l}\text { Reverse Slip } \\
(\mathrm{mm} / \mathrm{yr})\end{array}$ & $\begin{array}{c}\text { Left-Lateral Slip } \\
(\mathrm{mm} / \mathrm{yr})\end{array}$ & $\begin{array}{l}\text { Net slip } \\
(\mathrm{mm} / \mathrm{yr})\end{array}$ & $\begin{array}{c}\text { Reverse Slip } \\
(\mathrm{mm} / \mathrm{yr})\end{array}$ & $\begin{array}{c}\text { Left-Lateral Slip } \\
(\mathrm{mm} / \mathrm{yr})\end{array}$ & $\begin{array}{l}\text { Net Slip } \\
(\mathrm{mm} / \mathrm{yr})\end{array}$ \\
\hline Palos Verdes & $0.26-0.38$ & -2.5 to -3.8 & 0.0 & -3.2 & 3.2 & 0.0 & -3.2 & 3.2 \\
\hline San Gabriel & & -1.0 to -2.5 & 1.7 & -1.5 & 2.3 & 1.7 & -1.5 & 2.2 \\
\hline Sierra Madre East & $0.1-5.0$ & & 2.3 & -0.2 & 2.3 & 2.2 & -0.2 & 2.2 \\
\hline Cucamonga & $>4.5$ & & 1.9 & 0.8 & 2.1 & 1.9 & 0.8 & 2.1 \\
\hline Whittier/Glen Ivy & & -1.0 to -3.0 & 0.4 & -1.8 & 1.8 & 0.4 & -1.8 & 1.8 \\
\hline Sierra Madre West & $0.6-2.2$ & & 1.5 & -0.6 & 1.6 & 1.3 & -0.6 & 1.4 \\
\hline Northridge & & & 1.2 & -0.4 & 1.3 & 1.2 & -0.4 & 1.3 \\
\hline Chino & & -0.35 to -1.9 & 1.0 & -0.7 & 1.2 & 1.0 & -0.7 & 1.2 \\
\hline Newport-Inglewood & & -0.3 to -1.5 & 0.2 & -1.2 & 1.2 & 0.1 & -1.2 & 1.2 \\
\hline Fontana & & & 0.2 & 1.0 & 1.1 & 0.2 & 1.0 & 1.1 \\
\hline Lower Elysian Park & & & 0.6 & -0.6 & 0.8 & 0.8 & -0.6 & 1.0 \\
\hline Santa Monica & $0.5-1.3$ & & 0.8 & 0.6 & 1.0 & 0.7 & 0.6 & 1.0 \\
\hline Workman Hill & & & 0.6 & -0.8 & 1.0 & 0.6 & -0.8 & 1.0 \\
\hline Verdugo/Eagle Rock & & & 0.5 & -0.6 & 0.8 & 0.7 & -0.6 & 0.9 \\
\hline Clamshell-Sawpit & & & 0.4 & 0.7 & 0.8 & 0.4 & 0.7 & 0.8 \\
\hline Raymond & & $>1.5$ & 0.7 & 0.9 & 1.2 & 0.4 & 0.6 & 0.8 \\
\hline San Jose & & & 0.4 & 0.6 & 0.7 & 0.4 & 0.6 & 0.7 \\
\hline Uplands & & & 0.3 & 0.6 & 0.6 & 0.3 & 0.6 & 0.6 \\
\hline Hollywood & & $>0.35$ & 0.7 & 0.6 & 1.0 & 0.5 & 0.4 & 0.6 \\
\hline $\begin{array}{l}\text { Los Angeles/ } \\
\text { Las Cienegas }\end{array}$ & & & 0.5 & -0.1 & 0.5 & -0.6 & -0.2 & 0.6 \\
\hline Walnut Creek & & & 0.2 & 0.5 & 0.6 & 0.2 & 0.5 & 0.6 \\
\hline Peralta Hills & & & 0.5 & 0.0 & 0.5 & -0.5 & 0.0 & 0.5 \\
\hline $\begin{array}{l}\text { East Montebello } \\
\text { (Alhambra, WA) }\end{array}$ & & & 0.3 & -0.4 & 0.5 & 0.2 & -0.5 & 0.5 \\
\hline Puente Hills & $0.4-1.7$ & & 0.4 & 0.1 & 0.5 & 0.5 & 0.1 & 0.5 \\
\hline Upper Elysian Park & $0.58-2.2$ & & 0.3 & -0.1 & 0.3 & 0.5 & 0.0 & 0.5 \\
\hline San Joaquin Hills & & & 0.3 & -0.2 & 0.4 & 0.3 & -0.2 & 0.4 \\
\hline Compton & & & 0.3 & 0.0 & 0.3 & 0.3 & 0.0 & 0.3 \\
\hline Redondo & & & 0.0 & -0.3 & 0.3 & 0.0 & -0.3 & 0.3 \\
\hline San Vicente & & & 0.2 & 0.0 & 0.2 & 0.3 & 0.1 & 0.3 \\
\hline Richfield & & & & & & 0.2 & 0.1 & 0.2 \\
\hline
\end{tabular}

the Upper Elysian Park, Hollywood, Lower Elysian Park, Raymond, Sierra Madre West, and Verdugo faults (Table 1). The $0.2 \mathrm{~mm} / \mathrm{yr}$ reduction of reverse slip along the Western Sierra Madre fault is still within the geologic range (0.6 mm/yr; Crook et al., 1987; Rubin et al., 1998). The fault surface area on the Upper Elysian Park fault is unchanged, but revisions to the CFM model increase the reverse slip rates from $0.3 \mathrm{~mm} / \mathrm{yr}$ in model 1 to $0.5 \mathrm{~mm} / \mathrm{yr}$ in model 5 . The model 5 slip rate is closer to the geologic rates on the Upper Elysian Park fault $(0.58-2.2 \mathrm{~mm} / \mathrm{yr}$; Oskin et al., 2000) than the CFM-based model 1. A larger Lower Elysian Park fault area increases the reverse slip rate, but the faster rate of $0.8 \mathrm{~mm} / \mathrm{yr}$ is significantly less than the $1.3-2.1 \mathrm{~mm} / \mathrm{yr}$ estimated from geometric models (Shaw and Suppe, 1996). Between the CFM-based and the preferred model, the strike-slip rates decrease on the Raymond and Hollywood faults with the removal of the link between these faults. The preferred model slip rate for the Hollywood fault is within the paleoseismic estimate of $>0.35 \mathrm{~mm}$.yr (Dolan et al., 1997) and the geologic estimate of 0.5 to $0.6 \mathrm{~mm} / \mathrm{yr}$ (Meigs and Oskin, 2002). In contrast, the modeled Raymond fault strike-slip rate is $0.9 \mathrm{~mm} / \mathrm{yr}$ in model 5, which is slower than the lower bound of the geologic estimate (1.5 mm/yr; Marin et al., 2000). Connectivity with the nearby Verdugo and Eagle Rock faults likely influences slip rate along the Raymond fault and further alternatives might improve the mismatch.

These examples of slip rate changes without associated changes in fault surface area or dip further demonstrate the first-order effects of fault system configuration and connectivity on fault slip rates. Moreover, because the BEM models include off-fault deformations such as folding, the slip rates along the faults need not sum to the regional contraction rates. Several of the model variations tested here produced 
net decrease or increase in fault slip rates, while the overall contraction was balanced by changes in contraction accommodated between faults. Kinematic models, which assume that fault slip rates should sum to the overall deformation, neglect to consider the deformation that occurs between fault surfaces and are likely to misrepresent fault slip rates.

Changes to fault surface area between the CFM and the preferred model 5, which best matches the uplift pattern, may alter the degree of seismic hazard estimates on the active faults. Expanding the lateral extent of the Lower Elysian Park fault greatly increases the fault surface area available for rupture from 2030 to $3160 \mathrm{~km}^{2}$. Using the Wells and Coppersmith (1994) empirical relationship between rupture area and earthquake magnitude on reverse faults, this increase in fault area predicts in increase in earthquake magnitude on the Lower Elysian Park thrust from M 7.3 to M 7.5. A second notable difference is the decrease in area of the Puente Hills thrust system, from $1740 \mathrm{~km}^{2}$ in the CFM, which includes the LA segment, to $940 \mathrm{~km}^{2}$ in the preferred model, which consists of only the Santa Fe Springs and Coyote segments (Fig. 5). This $45 \%$ decrease in fault surface area implies that the maximum credible earthquake magnitude for the Puente Hills thrust would be proportionately smaller than reported previously and used in hazard assessments (Shaw et al., 2002; Dolan et al., 2003; Field et al., 2005).

\section{Conclusions}

A comparison of geologically defined patterns of uplift with models of uplift produced by boundary-element models for faults from the northern LA basin in the Southern California Earthquake Center's community fault model (CFM) was conducted. Model 1 uses the CFM version 2.5 fault geometry and produces uplift patterns that match the geologic uplift at the Santa Fe Springs and Coyote Hills anticlines but do not match uplift between the San Gabriel River and the Newport-Inglewood fault. To achieve better match in the western part of the northern shelf of the LA basin, we explored a variety of alternative fault configurations. The preferred model that best fits the geologic uplift data departs from the CFM in a number of significant ways (Fig. 5). Key differences include (1) using the $60^{\circ}$ dip from the Las Cienegas fault for the LA segment of the Puente Hills thrust system, (2) linking the steeper LA segment of the Puente Hills thrust system into the Lower Elysian Park thrust, (3) extending the Lower Elysian Park thrust along strike to the northwest, and (4) unlinking the Raymond and Hollywood faults. Incremental model-data improvement results from independent variation of fault dip, from linking and unlinking key faults, and from varying the lateral extent of blind thrusts; however, the most substantial improvements come from a model that integrates all the alternative geometries (compare Figs. 4 and 9). This result implies that connectivity exerts a strong control on fault behavior.

\section{Acknowledgments}

Authors Andrew J. Meigs and Michele L. Cooke contributed equally to this article. This research was supported by the Southern California Earthquake Center (SCEC). The SCEC is funded by the National Science Foundation's Cooperative Agreement EAR-0106924 and the U.S. Geological Survey's Cooperative Agreement 02HQAG0008. Three-dimensional modeling software was provided by Igeoss and Midland Valley. Gary Fuis, Mike Oskin, Andreas Plesch, and John Shaw are thanked for numerous discussions and encouragement. Thoughtful reviews by Juliet Crider, Mike Oskin, and Associate Editor Mark Hemphill-Haley improved both the analysis and presentation of our results. Della Fawcett assisted with the rock uplift analysis as part of Southern California Earthquake Center summer undergraduate research experience. The SCEC's Contribution Number for this article is 1110.

\section{References}

Allmendinger, R. W., and J. H. Shaw (2000). Estimation of fault propagation distance from fold shape: implications for earthquake hazard assessment, Geology 28, 1099-1102.

Argus, D. F., M. B. Heflin, G. Peltzer, F. Crampe, and F. H. Webb (2005). Interseismic strain accumulation and anthropogenic motion in metropolitan Los Angeles, J. Geophys. Res. 110, 1-26.

Birch, F. (1966). Compressibility; elastic constants, in Handbook of Physical Constants, J. Sydney and P. Clark (Editors), Geological Society of America, Boulder, Colorado, pp. 97-173.

Bjorklund, T. K. (2002). Evolution of the Whittier fold-fault system of the northeastern Los Angeles basin, California, Ph.D. Thesis, 128 pp, University of Houston, Houston, Texas.

Blake, G. H. (1991). Review of the Neogene biostratigraphy and stratigraphy of the Los Angeles basin and implications for basin evolution, in Active Margin Basins, K. T. Biddle (Editor), American Association of Petroleum Geologists Memoir 52, Tulsa, Oklahoma, 135-184.

Bullard, T. F., and W. R. Lettis (1993). Quaternary deformation associated with blind thrust faulting, J. Geophys. Res. 98, 8349-8369.

Buwalda, J. P. (1940). Geology of the Raymond Basin, California Institute of Technology, Pasadena, California, 131 pp.

Carena, S., and J. Suppe (2002). Three-dimensional imaging of active structures using earthquake aftershocks: the Northridge thrust, California, $J$. Struct. Geol. 24, 887-904.

Cooke, M. L., and S. T. Marshall (2006). Fault slip rates from three-dimensional models of the Los Angles metropolitan area, California, Geophys. Res. Lett. 33, 5.

Crider, J. G., and D. D. Pollard (1998). Fault linkage: 3D mechanical interaction between overlapping normal faults, J. Geophys. Res. 103, 24,373-24,391.

Crook, R., Jr., C. R. Allen, B. Kamb, C. M. Payne, and R. J. Proctor (1987). Quaternary geology and seismic hazard of the Sierra Madre and associated faults, western San Gabriel Mountains, in Recent Reverse Faulting in the Transverse Ranges, California, D. M. Morton and R. F. Yerkes (Editors), United States Geological Survey, Washington, D.C., pp. 27-64.

Davis, T. L., and J. S. Namson (1994). A balanced cross-section of the 1994 Northridge earthquake, southern California, Nature 372, 167-169.

Davis, T. L., J. Namson, and R. F. Yerkes (1989). A cross-section of the Los Angeles area: seismically active fold and thrust belt, the 1987 Whittier Narrows earthquake, and earthquake hazard, J. Geophys. Res. 94, 9644-9664.

Dibblee, T. W. (1982). Geology of the Santa Monica Mountains and Simi Hills, southern California, in Geology and Mineral Wealth of the California Transverse Ranges, D. L. Fife and J. A. Minch, (Editors), South Coast Geological Society, Santa Ana, California, pp. 94130.

Dibblee, T. W. (1989). Geologic Map of the Los Angeles Quadrangle, Los Angeles County, California, Dibblee Geological Foundation, Santa Barbara, California, Map DF-22, scale 1:24,000, one sheet. 
Dibblee, T. W. (1991). Geologic Map of the Hollywood and Burbank (South 1/2) Quadrangles, Los Angeles County, California, Dibblee Geological Foundation, Santa Barbara, Califiornia, Map DF-30, scale 1:24,000, one sheet.

Dolan, J. F., and T. L. Pratt (1997). High-resolution seismic-reflection profiling of the Santa Monica fault zone, west Los Angeles, California, Geophys. Res. Lett. 24, 2051-2054.

Dolan, J. F., and K. Sieh (1992). Tectonic geomorphology of the northern Los Angeles basin: seismic hazards and kinematics of young fault movement, in Engineering Geology Field Trips: Orange County, Santa Monica Mountains, and Malibu, P. L. Ehlig and E. A. Steiner (Editors), Southern California Section of the Association of Engineering Geologists, Los Angeles, California, pp. B20-B26.

Dolan, J., S. Christofferson, and J. H. Shaw (2003). Recognition of paleoearthquakes on the Puente Hills blind thrust fault, California, Science 300, 115-118.

Dolan, J. F., K. Sieh, P. Guptill, G. Miller, and T. K. Rockwell (1997). Active tectonics, paleoseismology, and seismic hazards of the Hollywood fault, southern California, Geol. Soc. Am. Bull. 12, 1595-1616.

Dolan, J. F., K. Sieh, and T. K. Rockwell (2000). Late Quaternary activity and seismic potential of the Santa Monica fault system, northwestern Los Angeles basin, California, Geol. Soc. Am. Bull 112, 15591581.

Dolan, J. F., D. Stevens, and T. K. Rockwell (2000). Paleoseismologic evidence for an early to mid-Holocene age of the most recent surface rupture on the Hollywood fault, Los Angeles, California, Bull. Seismol. Soc. Am. 90, 334-344.

Erickson, S. G. (1996). Influence of mechanical stratigraphy on folding vs. faulting, J. Struct. Geol. 18, 443-450.

Field, E. H., H. A. Seligson, N. Gupta, T. H. Jordan, and K. W. Campbell (2005). Loss estimates for a Puente Hills blind-thrust earthquake in Los Angeles, California, Earthq. Spectra 21, 329-338.

Ford, M., A. Artoni, E. A. Williams, J. Vergés, and S. Hardy (1997). Progressive evolution of a fault propagation fold pair from growth strata geometries, Sant Llorenç de Morunys, SE Pyrenees, J. Struct. Geol. 19, 413-441.

Fuis, G. S., T. Ryberg, N. J. Godfrey, D. A. Okaya, and J. M. Murphy (2001). Crustal structure and tectonics from the Los Angeles basin to the Mojave Desert, southern California, Geology 29, 15-18.

Griffith, A., and M. L. Cooke (2004). Mechanical validation of the threedimensional intersection geometry between the Puente Hills blindthrust system and the Whittier fault, Bull. Seismol. Soc. Am. 94, 493-505.

Griffith, A., and M. L. Cooke (2005). How sensitive are fault-slip rates in the Los Angeles basin to tectonic boundary conditions?, Bull. Seismol. Soc. Am. 95, 1263-1275.

Hardy, S., and J. Poblet (1994). Geometric and numerical model of progressive limb rotation in detachment folds, Geololgy 22, 371-374.

Hauksson, E., and L. M. Jones (1989). The 1987 Whittier Narrows earthquake sequence in Los Angeles, southern California: seismological and tectonic analysis, J. Geophys. Res. 94, 9569-9589.

Hauksson, E., L. M. Jones, T. L. Davis, K. L. Hutton, P. Williams, A. L. Bent, G. Brady, P. A. Reasenberg, A. J. Michael, R. F. Yerkes, E. Etheredge, R. L. Porcella, M. J. S. Johnston, G. Reagor, C. W. Stover, C. G. Bufe, E. Cranswick, and A. K. Shakal (1988). The 1987 Whittier Narrows earthquake in the Los Angeles metropolitan area, California, Science 239, 1409-1412.

Hudnut, K. W., Z. Shen, M. Murray, S. McClusky, R. King, T. Herring, B. Hager, Y. Feng, P. Fang, A. Donnellan, and Y. Bock (1996). Coseismic displacements of the 1994 Northridge, California earthquake, Bull. Seismol. Soc. Am. 86, S19-S36.

Huftile, G. J., and R. S. Yeats (1995). Convergence rates across a displacement transfer zone in the western Transverse Ranges, Ventura basin, California, J. Geophys. Res. 100, 2043-2067.

Johnson, K. M., and A. M. Johnson (2000). Localization of delaminated bedding in San Rafael Swell, Utah and other monoclinal folds, $J$. Struct. Geol. 22, 1455-1468.
Magistrale, H., S. Day, R. W. Clayton, and R. Graves (2000). The SCEC southern California reference three-dimensional seismic velocity model version 2, Bull. Seismol. Soc. Am. 90, S65-S76.

Marin, M., J. F. Dolan, R. D. Hartleb, S. A. Christofferson, A. Z. Tucker, and L. A. Owen (2000). A latest Pleistocene-Holocene slip rate on the Raymond Fault based on 3-D trenching, East Pasadena, California, EOS 81, 855.

Meigs, A. J., and M. E. Oskin (2002). Convergence, block rotation, and structural interference across the Peninsular-Transverse Ranges boundary, eastern Santa Monica Mountains, California, in Contributions to Crustal Evolution of the Southwestern United States, A. Barth (Editor), Geological Society of America, Boulder, pp. 279-293.

Meigs, A. J., N. Brozovic, and M. L. Johnson (1999). Steady, balanced rates of uplift and erosion of the Santa Monica mountains, California, Basin Res. 11, 59-73.

Meigs, A., D. Yule, A. Blythe, and D. Burbank (2003). Implications of distributed crustal deformation for exhumation in a portion of a transpressional plate boundary, western Transverse ranges, southern California, Quat. Int. 101-102, 169-177.

Molnar, P., and J. M. Gipson (1994). Very long baseline interferometry and active rotations of crustal blocks in the western Transverse ranges, California, Geol. Soc. Am. Bull 106, 594-606.

Myers, D. J., J. L. Nabelek, and R. S. Yeats (2003). Dislocation modeling of blind thrusts in the eastern Los Angeles basin, California, J. Geophys. Res. 108, no. B9, 2443, doi 10.1029/2002JB002150.

Nazareth, J. J., and E. Hauksson (2004). The seismogenic thickness of the southern California crust, Bull. Seismol. Soc. Am. 94, 940-960.

Nicholson, C., C. Sorlien, T. Atwater, J. C. Crowell, and B. P. Luyendyk (1994). Microplate capture, rotation of the western Transverse ranges, and initiation of the San Andreas transform as a low-angle fault system, Geololgy 22, 491-495.

Olson, E., and M. L. Cooke (2005). Application of three fault growth criteria to the Puente Hills thrust system, Los Angeles, California, USA, $J$. Struct. Geol. 27, 1765-1777.

Oskin, M., K. Sieh, T. K. Rockwell, P. Guptill, G. Miller, M. Curtis, M. Payne, S. McArdle, and P. Elliot (2000). Active parasitic folds on the Elysian Park anticline: implications for seismic hazard in central Los Angeles, California, Geol. Soc. Am. Bull 112, 693-707.

Plesch, A., J. H. Shaw, C. Benson, W. A. Bryant, S. Carena, M. L. Cooke, J. Dolan, G. Fuis, E. M. Gath, L. Grant, E. Hauksson, T. Jordan, M. Kammerling, M. Legg, S. Lindvall, H. Magistrale, C. Nicholson, N. A. Niemi, M. Oskin, S. E. Perry, G. Planansky, T. Rockwell, P. Shearer, C. Sorlien, M. P. Suss, J. Suppe, J. Treiman, and R. Yeats (2007). Community fault model (CFM) for southern California, Bull. Seismol. Soc. Am. 97, 1793-1802.

Rockwell, T. K., E. M. Gath, and T. Gonzalez (1992). Sense and rate of slip on the Whittier fault zone eastern Los Angeles basin, California, in Proceedings of the 35th Annual Meeting of Engineering Geologists, M. L. Stout (Editor), Association of Engineering Geologists, Santa Ana, California, 679.

Rubin, C. M., S. C. Lindvall, and T. K. Rockwell (1998). Evidence for large earthquakes in metropolitan Los Angeles, Science 281, 398-402.

Savage, H., and M. Cooke (2003). Can flat-ramp-flat fault geometry by inferred from fold shape?: a comparison of kinematic and mechanical folds, J. Struct. Geol. 23, 203-2034.

Savage, H., and M. Cooke (2004). An investigation into the role of fault interaction on fold pattern, J. Struct. Geol. 26, 905-917.

Schneider, C. L., C. Hummon, R. S. Yeats, and G. J. Huftile (1996). Structural evolution of the northern Los Angeles basin, California, based on growth strata, Tectonics 15, 341-355.

Seeber, L., and C. C. Sorlien (2000). Listric thrusts in the western Transverse ranges, California, Geol. Soc. Am. Bull 112, 1067-1079.

Shaw, J. H., and P. M. Shearer (1999). An elusive blind-thrust fault beneath metropolitan Los Angeles, Science 283, 1516-1518.

Shaw, J. H., and J. Suppe (1996). Earthquake hazards of active blind-thrust faults under the central Los Angeles basin, California, J. Geophys. Res. 101, 8623-8642. 
Shaw, J. H., A. Plesch, J. F. Dolan, T. L. Pratt, and P. Fiore (2002). Puente Hills blind-thrust system, Los Angeles, California, Bull. Seismol. Soc. Am. 92, 2946-2960.

Stein, R. S., G. C. P. King, and J. B. Rundle (1988). The growth of geological structures by repeated earthquakes 2 : Field examples of continental dip-slip faults, J. Geophys. Res. 93, 13,319-13,331.

Suppe, J. (1983). Geometry and kinematics of fault bend folding, Am. J. Sci. 283, 648-721.

Suppe, J., and D. A. Medwedeff (1990). Geometry and kinematics of faultpropagation folding, Ecol. Geol. Helv. 83, 409-454.

Suppe, J., F. Sàbat, J. A. Muñoz, J. Poblet, E. Roca, and J. Vergés (1997). Bed-by-bed fold growth by kink-band migration: Sant Llorenç de Morunys, eastern Pyrenees, J. Struct. Geol. 19, 443-461.

Thomas, A. L. (1994). POLY3D: a three-dimensional, polygonal element, displacement discontinuity boundary element computer program with applications to fractures, faults, and cavities in the Earth's crust, Master's Thesis, Stanford University, Palo Alto, California, $52 \mathrm{pp}$.

Tsutsumi, H., and R. S. Yeats (1999). Tectonic setting of the 1971 Sylmar and 1994 Northridge earthquakes in the San Fernando Valley, California, Bull. Seismol. Soc. Am. 89, 1232-1249.

Tsutsumi, H., R. S. Yeats, and G. J. Huftile (2001). Late Cenozoic tectonics of the northern Los Angeles fault system, California, Geol. Soc. Am. Bull 113, 454-468.

Ward, S. N., and G. Valensise (1994). The Palos Verdes terraces, California: bathtub rings from a buried reverse fault, J. Geophys. Res. B99, 44854494.

Weaver, K. D., and J. F. Dolan (2000). Paleoseismology and geomorphology of the Raymond fault, Los Angeles County, California, Bull. Seismol. Soc. Am. 90, 1409-1429.

Wells, D. L., and K. J. Coppersmith (1994). New empirical relationships among magnitude, rupture length, rupture width, rupture area, and surface displacement, Bull. Seismol. Soc. Am. 84, 974-1002.

Woodward, N. B., S. E. Boyer, and J. Suppe (1989). Balanced Geological Cross-Sections: An Essential Technique in Geological Research and
Exploration, American Geophysical Union Short Course in Geology, Vol. 6, 132 pp.

Working Group of California Earthquake Probabilities (WGCEP) (2006). Fault section database 2.0, http://gravity.usc.edu/WGCEP/resources/ data/refFaultParams/fltSectData2.html, and references therein (last accessed January 2008).

Wright, T. L. (1991). Structural geology and tectonic evolution of the Los Angeles basin, California, in Active Margin Basins, K. T. Biddle, American Association of Petroleum Geologists Memoir 52, Tulsa, Oklahoma, 35-134.

Yeats, R. S., and G. J. Huftile (1995). The Oak Ridge fault system and the 1994 Northridge earthquake, Nature 373, 418-420.

Yerkes, R. F. (1972). Geology and oil resources of the western Puente Hills area, southern California, U.S. Geol. Surv. Profess. Pap. 420-C, 63 pp.

Yerkes, R. F., T. H. McCulloh, J. E. Schoellhamer, and J. G. Vedder (1965). Geology of the Los Angeles Basin, California: an introduction, U.S. Geol. Surv. Prof. Pap. 420-A, 1-57.

Department of Geosciences

Oregon State University

104 Wilkinson Hall

Corvallis, Oregon 97330

(A.J.M.)

University of Massachusetts

611 North Pleasant Street

Amherst, Massachusetts 01003-9297

(M.L.C., S.T.M.)

Manuscript received 8 December 2006 